University of Massachusetts Amherst

ScholarWorks@UMass Amherst

Masters Theses 1911 - February 2014

1931

\title{
The effect of some forms of nitrogen on the growth and nitrogen content of wheat and rice plants
}

Guy. Thelin

University of Massachusetts Amherst

Follow this and additional works at: https://scholarworks.umass.edu/theses

Thelin, Guy., "The effect of some forms of nitrogen on the growth and nitrogen content of wheat and rice plants" (1931). Masters Theses 1911 - February 2014. 2029.

Retrieved from https://scholarworks.umass.edu/theses/2029

This thesis is brought to you for free and open access by ScholarWorks@UMass Amherst. It has been accepted for inclusion in Masters Theses 1911 - February 2014 by an authorized administrator of ScholarWorks@UMass Amherst. For more information, please contact scholarworks@library.umass.edu. 
The Effect of Some Forms of Nitrogen on the Growth and Nitrogen Content of Wheat and Rice Plants

\author{
Guy Thelin
}




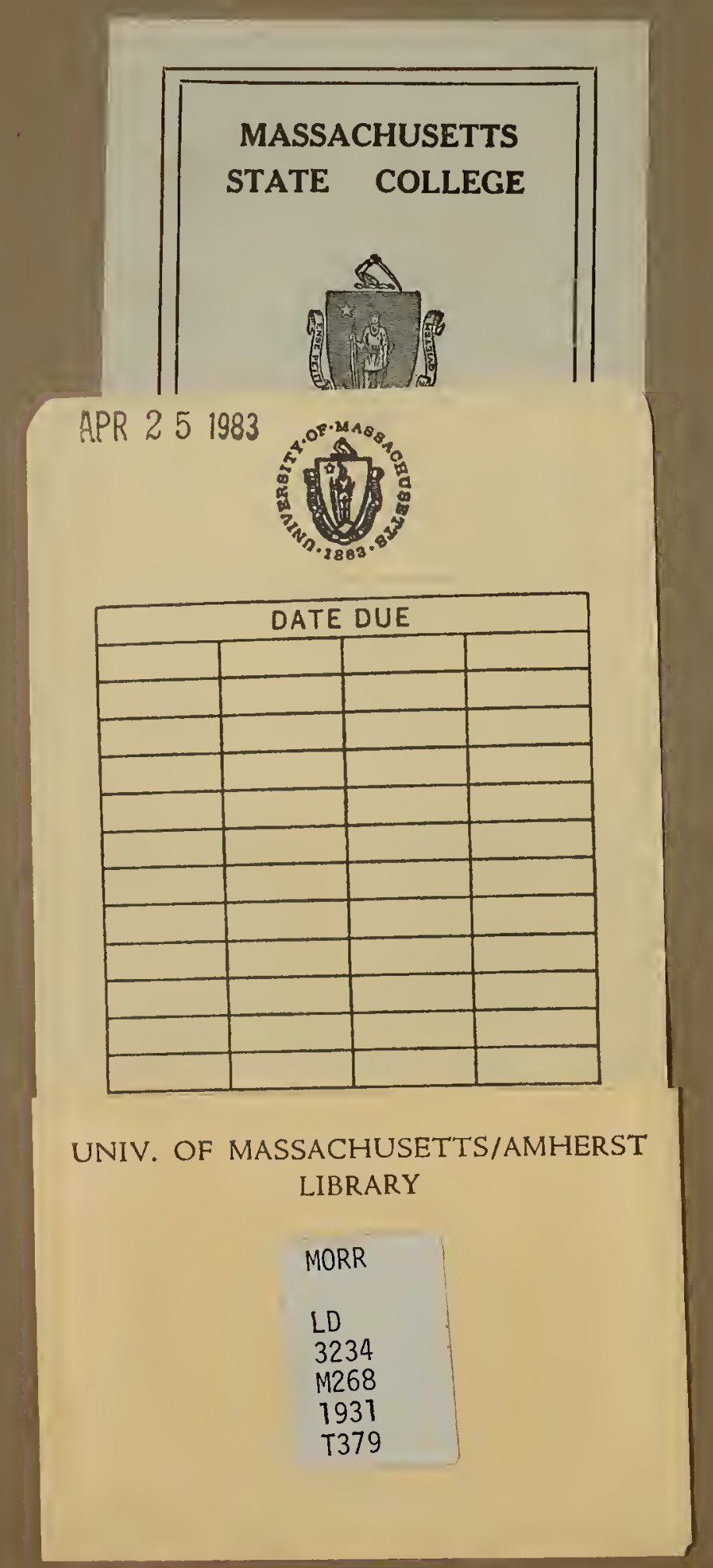




\section{The sffect of Some Forms of llitrogen on the Growth and Nitrogen Content of Wheat and rice plants}

by

Guy The1in

Thesis Subal tted for the Dogree of laster of siclence

Departusent of Afronony

Rassachusetts State College

Amherst, Hassachusetts

1931 


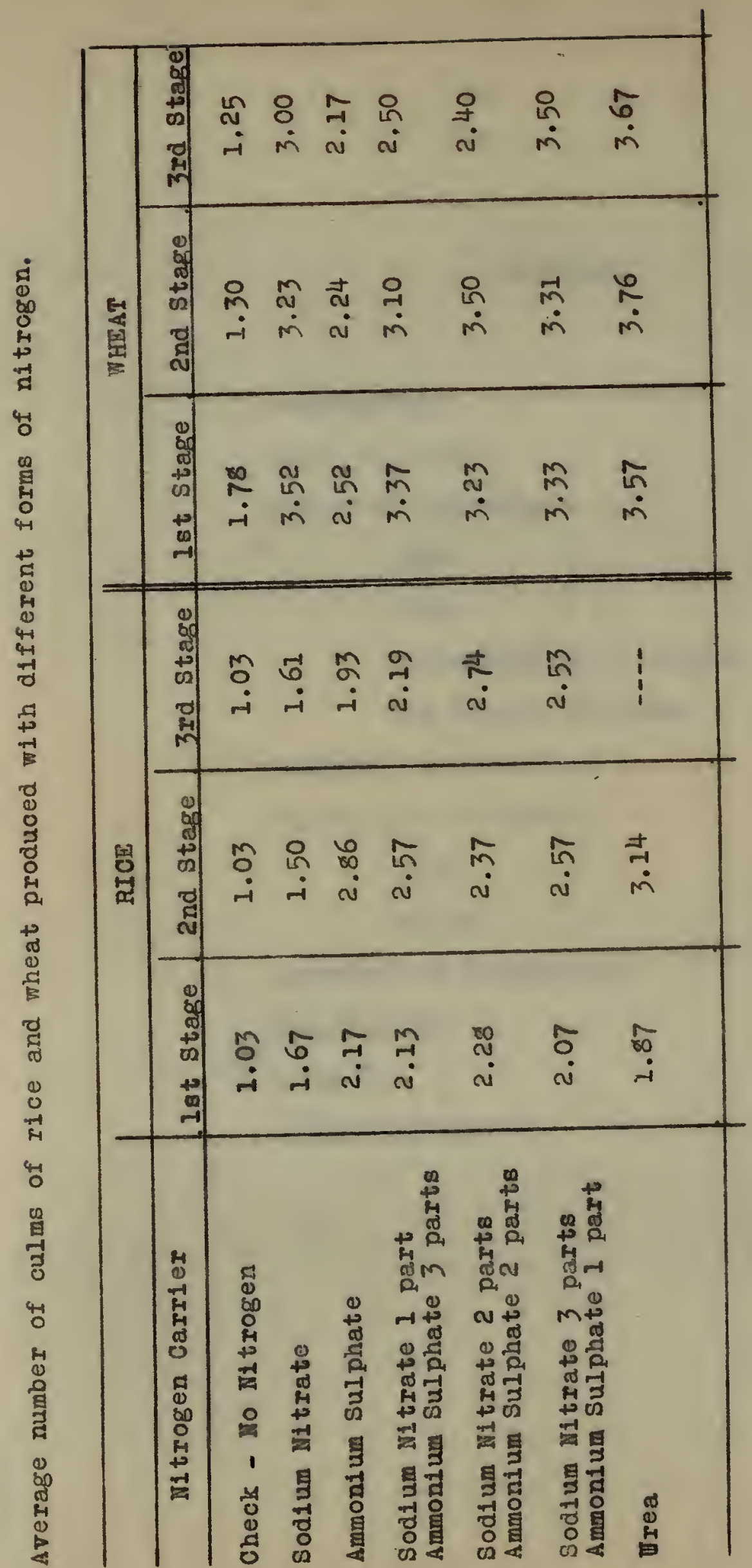




\title{
COMPEITS
}

\author{
Introduction \\ Scope of Thesis \\ Revien of usterature \\ Pice \\ wheat \\ Acrimilation of Apronic \\ and Mitric nitrogen \\ tethods and Procedure \\ Discusion of nesults \\ rice \\ wheat \\ Stumary and Conclusions \\ Mbliography \\ Appendix \\ Acl non ledgenents
}




\section{Introduction}

Since the dawn of research in plant sclence plent phyalologiats and agronomists have been interested in the problems of plant nutrition. The problen of the assinilation of nitrogen by economic plants continues to be one of the chief problens to occupy the attention of many invostigators engaged in agronamic research. For the agronomist, the fertilizer manufacturer, and the practical farmer, the question of the effect of alfierent forms of nitrogen on plant growth has for many years bean of primary inportance in the intelifigent study and uso of nitrogenous fertilizers. With the increasing production of the symthetic forms of nitrogen compounds this guestion has assuned more Interest and importance.

It Is known that plants are able to asuinilate nitrogen frow either inorefanic or organic sources. From early investigations on the assimilation of nitrogen from various inorganic salts, it has generally been conceded that nitrorten in the nitrate form is the best form for higher plants. the Irwland rice plant, however, is the exception to this assumption in that it prefere nitrogen in the armonium form. A fer investigatars have 
observed that a combination of the nftrate with amonium nitrogen gives increased growth and vigor to growling plants. This has also been substantiated by $c$ ome very recent investigations ( 30 ).

Since the comparative value of different forme of $n d-$ trogen absorbed by plants is usually determined by the total yield of ary mater, their effect on growth is of utmost importance. Nut nitrogen aseimilation depends also on the amount and character of the nitrogen content of the plant. It is known, for exaple, that some plants may accumulate nitrogen by absorption, which they are not able to assinilate. This phate of the probles has here-tofore recalved but 1 ittle consideration.

The author has been privileged to serve for several. years in China, where rice and wheat are the most inportant two crops of the people, and is therefore especially interested in the problen as it affects these two plants. 
This thesis deals with the study of the effect of some forms of nitrogen on the growth and nitrogen content of rice and wheat plants. Both organic and inorganic foms vere ued, urea as the source of the former, and armonius sulphate, and sodium nitrate as sources of the latter. Combinations of arsonium sulphate and sodium $\mathrm{m}$ trate in afferent proportiono vere also used. Dry velghts of plants were obtained, and deterninations of total, nitric and anonic nitrogen sade. Data were secured also on changes in the reaction of the nutrient solution, nuber of plant culns and genoral growtin conditions.

The ary satter produced, anount and character of ntrogen absorbed, character of growth and behavior of the plant, have been used as criteria of assinilation of the different nitrogen forms used. 
Pethods and Procedure

In these investigations with solution cultures, Vintula rice, an early raturing variety of lowland rice fumished by the Jnited States Department of Agriculture and srown last year at the peleral Agricultural ixperinent Station located at Crowley, Loulalana, and Marguis wheat were used. The seed sanples were treatod with Semesan disinfectant and later submerged in tap vater at roon tempersture for several hours. Then the aeeds were drained fres of water and alloved to sprout. hs soon as the sprouts appeared they were placed upon a parafrined bobuinet, which was stietched tightly over the mouth of a four gallon crock. The vater in the crock which came to the surface of the bobbinet, was replensohed wth fresh water fran time to time. Mese Jars were placed in the greenhouso and were subjected to the same degree of terapernture, hunidty and light.

Whe $n$ the scedinge were eight to ten centiseters in height, unfform vigorous seedings were selected ant inserted into large paraffined corss which were a trifle smalier than the mouths of one quart fruit preserving jars, slallar to the manner omployed by rottInghwa ( 49 ). Each cork contained six plants. These 
corks were Inserted into thin Iron plates and jars enclosed after the manner described by Beaunont and Larginos $(4)$ ). The following mineral nutrient solution, a modification of Crone's, which has given good results whth cercal plants, Erasses and tobacco, was used :

$$
\begin{aligned}
& \mathrm{CallPO}_{4} \cdot 2 \mathrm{H}_{2} \mathrm{O} \text {-.....- } 0.0022 \mathrm{~mol} \text {. }
\end{aligned}
$$

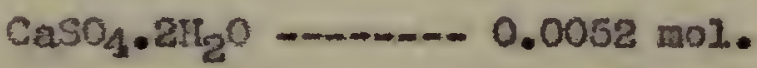

$$
\begin{aligned}
& \mathrm{IgSO}_{4}+7 \mathrm{~F}_{2} \mathrm{O} \ldots \ldots \ldots-0.0114 \mathrm{~mol} \\
& \text { xC1 -. - }
\end{aligned}
$$

Since the nutrient solutions vere charged tvice weekly only one fourth full strength vas used during the carly stares of growth and later increased to half 6trength ( 5 ). To the one-fourth full strength mineral nutrient solution mantanese sulphate and boric acid vere added at the rate of one part per millian of ranganese axd boron respect 1 vely, and $0.0278 \mathrm{~mol}$. nitrate of soda or other nitrogen aaterialo or conbinations of materiale having an equivalent anount of nitrugen in every case. The stock solutions of nitrogen materials were prepared each week and tests showed that there was no deterioration in any of those solutions. The stoci: solutions were mude from Baker's C.P. salts and listilled water, but nitrogen $f$ ree tap water was used in preparing the complete nutrient solution for plant uge. The source of lron was ferric 
potasslum tartrate first used at the rate of flve milliliters of a 0,1 per cent solution. This was found sufficient for the young wheat plants but ineufficient for rice. Consequently, the anount was Iive sillilitare of a 0.5 per cont solutfon.

The freshly prepared mutrient solution has a reaction value of pir 6.4 to 6.6. Once each week the reactions of the used nutrient solutions were deternined colorimetrically in arder to observe the reaction changes. of the various nitrogen carriers.

The following series of nitrogen aaterinls were used:

1. Urea

2. Hitrate of soda

3. Aawonius sulphate

4. Combinntion of one part nitric nitrogen fron sodiun nitrate and three parts amoonie nitrogen from amonius sulphate.

5. Combination of equal parts of nitric and amsonic nityogen from sodum nitrate and armonium sulphate, respectivoly.

6. Corbination of three parte nitric nitrogen fros sodiun nftrate and one part ansonic nitrogen from anmoniun sulphate.

To this was added a no nitrogen lot for control. Five replications of six plants each were rade of each lot 
In orler to provide a sufficlent number of plants for setisfactory results. There were three series each of whent and rice, one for each stage of growth studied.

These cultures were grown in the groenhouse under nearly unifory conditions of light, humdity and temperature, but tap water at roow terperature was used in making up the reneved nutrient solutions for the young rice plants.

The three series plants were harvested at intervals of appoximately one month, two months, and three month, respectively and condition of plants recorded. These harveated plants were placed lrabedately into a oven and. thoroughly drlea at a temperature of stxty degrees centigrade. When thoroughly dry thoy were weighed and weights of tops and roots recoried soperately.

The analyses for inorganle nitric nitrogen and asamonte nitrogen was made according to the mothod of Session ( 42 ) and Sessions and shive ( 41 ) except that the dried material was used instead of the plant extracts. The arfed planta were ground to pass a 20 medh siove or finer and then placed in a ball nill for two and a half to thee hours, after which time most of the materlal would pass thru a 100 mesh sieve. any tixe flnos material was uตed in the inorganic ntrogen deterulnations. rotal nitrogen was deternined by $1 x^{2}$. P. H. Wath of the . 


\section{Review of Literature}

Rice

Keliner ( 22 ), in 1384 , foun in pot experiments that amoniun salts produced better growth during the early development of rice plants but during later growth nitrates proved more effective. In the paddy soils of Japan Kollner ( 23 ) also showed that amonia is formed in rather large quantities whie nitrate fornation was very clow.

Wagcalca ( 31 ) In Japan concluded that amonium alphate and soy bean cake vere more effective than nitrates with lowland rice. Ite found that the value of arnonturs sulpinte and nitrete of sock stand in the ratio of 100 to 40 . However, In his worle on the ananial value of calciun cyanamia ( 32 ) his data show that nitrate of goda produced greater total yield than anrontum sulphate, but that these two foms wore better then calciun cyanantd in pot experinutes with transplanted plants of lowland or paddy $x$. 1 ee.

Dalkuhara and Inaseki ( 6 ) found that araonitum sulphete was more effective than either nitrate of soda or a combination of the two forms. With ary or upland rice, however, these two forms proved to be about of egual value. 
In flawalian field trials kelly ( 24 ) showed that applications of ammonium sulphate produced considerable Increases in ylelds of straw and grain. Applications made before planting produced better ylelds compared with applications at intervals of growth. Hitrate of soda was inefective in either case. In pot experinents with soil cultures nitrates were ineffective until near the healing period of rice. Soy bean calce, a common forra of fertilizer in the ortent, produced very good growth, but arimonium sulphate was the most effective and produced not only freater helght of plants but increased tillering over the nitrate culures. Fhe applications of nitrates in sand cultures showed very unhealthy and stunted growth, witere as applications of amonium sulphate produced healthy nomas grovth.

(13)

Gile and Carero/In porto Mco in their invostigations on the problex of assimilation of lron by rice concluded that ferrous sulphate, femle chloride, and ferric tartrate afforted sufficient iron in acld and netutral solutions, but only ferric tartrate furmished ouficient iron lit alkaline solutions. Those plants grom in acid aolutions contained the highest percentages of iron. 1utrient solutions supplied w1th 0.008 ram of iron per Itter protuced much better growth than with 0.002 grans of Iron per Iiter. They concluded that rice is not. 
particularly sensitive to the reaction of the nutrient colutions except as the reaction influenced the availabllity of the iron. They also found that there was no assinilation of colloldal lron by rice plants (14).

alle and Carrero (15) found in the1r worti an the absorption of mutrients as afected by the number of roots supplied with the nutrient solution, that plants with all thelr roots in the nutrient solution absorboc the taxximun total anount of the elesents, ant the fower the murber of roots the smaller the total anount absorbed; thnt the exount of the eleatent absorbed per gras of roots inereased greatiy as the number of the roots in the nutrient solution alminished.

lising the triengralar method of varying aalt proportions with solution, sand, and soll cultures trelease and paulina (50) studied the effect of the adiltion of varying anounts of annonis and nitrate salts on the growth of rice. They found that there was a direct relation of high ylelds of straw and grain to high proportions of nitrogenous alts in fert11zer mixtures. The best cultures of amnoniun sulphate, ansonium nitrate, sodium nitrate, calclum nitrate, gave yields of 0.6 , $6.5,3.2$, and 3.0 times, respectivaly, that of tize control cultures The armontur form of nitrogen was superior 
to the nitrate form in every case.

(10)

Ispino An 1920 studied the salt requircrents of young rice plants in which he grew lowland rice in various corbinations of salt solutions during the three wecks period Pollowing germination. These studieb, he states, "Involve experinemtal dats on the growth of the rice plants in three different types of solutions: 3-salt solution type I comprising, bestacs a trace of forric phosphate, the three salte monopotassium phosphate, celclun nitrate, and menesium sulphate; 4-salt solution type $A$ comprlsing, bostales a trace of ferric phowphate, the three salts just mentioned together with amonius sulphate; and 4-6alt solution type coaprialnc, besides a trace of forric phosphete, the four anlts monopotassium phosphate, vonocalciun phosphate, magnesiun sulphate, and armoniw oulphate. rach type was studied with reference to a large nuber of afferent sets of salt proportions and several different total concentrations." These types were arranged on the basts of nolecular proportLons and not osmotic proportions. Ie concluded that no 3-salt type I set of proportions gave good growth, but excellent growth was obtained with proper sets of the 4-salt type A solutions, which indicate that plants require the armonium Lon. Espino further concludes that the nost promislus solution for rice plants will have 
about 0.002 grans molecule per liter of all salta, with the salts belng present in about the following proport1ons:

Honopotass Iura phosphate one part,

Amonium sulphate one and one hals parts,

Calciua nitrete one and one hale parts, and

hagnesiue sulphate four parts.

Tis seers to indicate that not only is the amontwo ion reguired but also the nitrate Ion for the growth of rice plants.

Jacobson ( 17 ) found that oighty per cent of the cotal nitrogen of the culture solution was removed by the 100 day old rice plants during three days of the experiswent in whos the hydrogen ion reaction was abserved. The pol values of the rutrient solutions chenged frow an average 1ritiel actaty of pll 5.0 to pll 3.0 after growIng the plants for one three day period. This increase In the hydrogen ion concertration was more marised after photosynthesis has ceased indicating that tire carbon-aloxlde given of by the roots was absorbed by the cultural solution.

In his experiments on the nutritive values of difrerent salts of armonie, palisoc ( 34 ) found, in using Foplno" s method of salt solutions, that amoniun nitrate was the best, awanlum sulphate second, and axnonium 
phosphate was the poorest of all the smonitum salta used. The Intter prodisced a phyolological infury characterized by the drying of the tips of the leaves of the joung plents. Ife also found that a nutrient colution compoed of one part monopotassius phosphate, four parts araxonium nltrate, two parts calcium rutrate, and four parts magneslum sulphate with a total concentration of 0.00275 gram molecule per liter wa better than Dsplno's best Amealt solution.

The relation of sodium nitrate, andoniun mulphate, and grean forure to the covelopment of chlorosis in rice with soll cuItures was studied by wetzger and Janssen ( 27 ). They found that chlorosis in rice, occurred in most cases before pur 6.0 was reached, wa apporently due to the lack of available nitrogen, winch was overome as

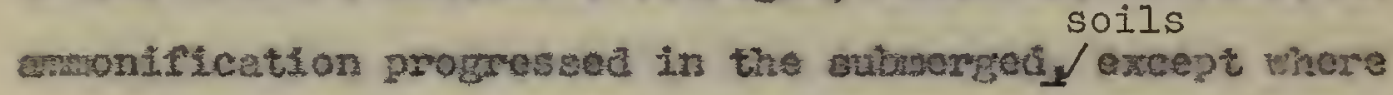
organic noter was in abundance. Sproying ferroub culphate on the laves of chicrotic plarts or the adaltion of Perrle citrate to the flood water failed to correct the condition.

In theis impestigations on the transformation of nitrogen in rice soils Janwsen and Hetager ( 19 ) used soll ctltures trated with sodiur nitrate, armonilus aulphate, and soy beans gas gren manure, under untlooded and submerged, cropped and uncropped conaitlons. 
Their rooults show that the nitrate content of the soll was never signifieant in any or the tests. In the cultures trented wh arvonium sulohate it was observed. that there was a decided decrease in frronia content and a corresponding increase of nituates for the unflooded soils. In the subnerged serios the ammonia decreased and at the sare tine nitrates also decreased to tho extent as to be practicn.ly insignifleant in amount. A comparison of cropped vitr uncropped cutumes whow that nturates were reduced In the flooded soils by croping. In those cultures treatod with solum nitrate the submerged solis show that tite amount of nitrates decreased to a trace in the two-month period, while there was no signifleant anount of amonia rorned. In the unflonded solis the seluction of the nitrates was not as merked. whe green manume trentments of the subserged solis showed a steacy Inerease in amonia but very small amounts of nitrates at ary tine. In the unflooded golla thers was an Increasc followed with a decrease in the armonta content but the nitrate content increased during the tro month perioc. Janssen and Hetager conclude that ammonia is superior to nitrates as fortilizors either in the rorna of armonius sulphate or green manure, but that 
rice plents do essimilate nitrates to a considerable extent in the care of dry colls.

Bartholomen ( 2 ) found that the altrocrenous fertilizers nay be alvided according to their effect on the hyarrogen-1on concentration under anaeroble conditiosa into three rroups:

1. Acid protucing - such as anonium aulphate, Leunasalpeter, amophos, and uxea.

2. Alkaline producing - such as sodiun nitrate. calchun nitrate, and calciun cyananda.

3. ractically non-reacting - such as cottonsed meal and blood menl.

Ie concluted that the changes in hyarogen ion concentration under the conditlons of the investigations in which rleo was the crop used, were due largely to asolnilation of the nitrogen by plants and bacteria, altho sone changes may be due to the liberation of elemental nltrogen. Ite states thst Falure to control changes in hydrogen-ion concentration in studies concernang the avallability of ntrogenous fert1hates may lead to erroneous interprotations of results.

In another seried of investigations Bertholomew ( 3) studied the avallability of nitrogen fertilizors to rice in and cultures. He states that "nitrogen 
whether in nftrate, organic, or axconia form seens to be readily available for rice if other growth factors such as reaction, terperature, and 11 ght are mnintained uniforn for all treatrente." Fe found trat the exiciency of the following nitrogen conpounds compared with armonium sulphate as 100 to be: Leunasalpeter $36 \%$, a mature of cottonseed real and armonium mulphete 96\%, urea $32 \%, \mathrm{ni}-$ trate of soda 82.5\%, blood meal 87\%, amonim phouphate 8.5., calciu cymand 69.5\%, a mixture of cottonsecd meal and nitrate of sxda $66 x_{\text {, }}$ cottonsed meal 61.59 , and

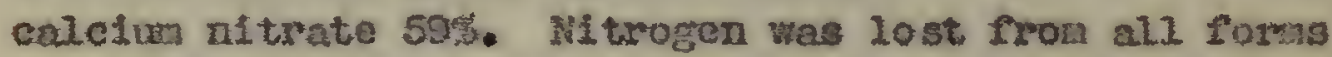
of mitrogen, whether st was in the amonia, nitrate, or organic forn, sut trere were greater anounts/ fros the nitrates and organic nitrogen conpounds. Dentriflcation took place so rapidly that the nitrato content was insignificant.

Several investigators, Loew and Sowa ( 25), Aso ( I ), end Fagooks ( 31 ) have observed that manganese has a benericial influence on the rtce plant on paldy aotis of Japan.

Gericke ( 11 ), using seven types of solutions in which one element was deflcient and a complote nutrient solution of all types, found that rice plants, comparable to those grown under field condtions, could be grown 
succesofuly without the use of axmontm salts. Boron and manganese at the rate of one part per milition, and ferric tartrate as the source of iron, rere used. The eolutions were composed of equel fractional nole concentrations and had an osmotic value equal to one atnosphere of probsure. Plants were grown for four vecirg In complete nutulent solution and then at intervals of two wecks were trancferred to solutions in which ane element was lacking in order to study the salt roguirement of the rice plant. Wo element vas exhaurted except iron and no solutlono were renewed.

This indicates that the wace plent has a low absorptive capacity for iron. Fe also foun that the rice plantis utilized larger amounta of potassiun and ritrogen indicating thet those two lons eare apparently palred. Gerick states that, "The apsent greater need of rice for these elements, both as to quantity requfred and as to the length of time they need to be avallable, reduces the factors which markedy affect the growth or pice in rutrient solutions, to the conditions that control the avallability of iron, ntrogen, ana potassium." 
wheat

Mutchinson and t11er ( 16 ) grew wheat plants in sterile sand and vater cultures with amonitum sulphate as the source of nitrogen. They found that with sterile water culturss the grovth of the plants vas slow ant the root growth very poor. phe sterile cultures vith amonlue salphate and rineral solution which were inoculated vith nitrifying organlams proved fas superior in yield of dry natter and total nitrogen in crop but contalned a amaller percentage of nitrogen in the dry natter. They concluded thot wheat plants showd a declded preference for nitrogen in the form of nitrate.

Using the triangle syster of nolecular salt propor-

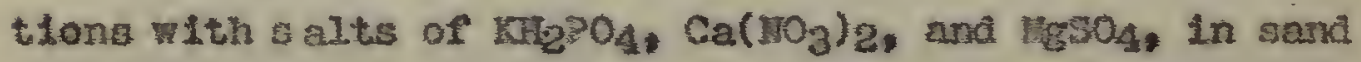
cultures with mhest sevel1 (43) obtalned maximun grain yields with high solecular proportions of nitrogen and $10 \mathrm{~m}$ phosphorus enl potassiun salta proportion or with low nitrogen and high phowphorus and potasolur salt proportions.

bavidson and Leclere ( 7 ), from field experiments, found that the presence of sodiun nitrate in the soli at the early stages of growth stimulated the vegetative gronth of the wheat crop and resulted in greater yields. Applications of sodium nitrate at the tine of heading did not affect the vegetative growth, but gave a better quality of grain judglas from its appearance and protein content. 
No noticeable effect was observed on the crop when applicatlons of sodium nitrate wers made at the tine the grain was in the milk stage. They also observed that appliat

cathons of the nitrate/healng stage increased the protein content of the strav, and at the first wage the yield of straw and grain was increased.

Davidson ( 8 ) from the results of later field experiments concludes that "The effectveness of nitrates in increasing ylelds decreases consistertiy as the tine of their appllcation approaches the stare of hading." Ana whe effectiveness of nitrates in increasing the protein content of the grain increases as their effectiveness in increasing the ylela decreasos."

In atudy of factors affocting the nitrogencontent of wheat and the changes that occur during the development of wheat olsen ( 33 ) states that the percentage of nitrogen in the plant proper decrease with the continuous growth of the plant. Te show that the nitrogen percentage of the kernel aecreases with the progresofve development and Increased welght of the kernel when grown under field conditions. If conditions are favorable for nomal development, all the excess nitrogen in the different prots of the plant will be moved upward and tranaferrod Into the kernel. alsen also observed that phoaphorus entered tive grain siralteneously with nitrogen except in 
the early stages of development.

Jacobson ( 18 ) observed the changea in hyürogen-1on concentration with tarquis wheat plants 97 days old which were pleced in cultural solutions with molecular proportions alstributed in one eightis. He found that the pll value increased from 3.9 to 6.3 during the Pret twolve hours after which the reaction resalned fairly constant for the 72 hour perlol of observatian. The nitrogen concentration decreased fron 85 to 24 part per million of nitrate nitrogen, a los3 of nearly 72 percent of the total nitrogen during the flrst twelve hour poriod. only a trace of nitrogen was found at the end of the 36 hour period.

Fas and roble ( 48$)$ grev Eecdinge of wheat, corn and soybeans in nutrient solutions of aifrerent hydrogen Ion concentrations of constant values ranging from pif 3 to 8. Maximum growth of wheat seduings occurred when the hydrogen-1on concentration was maintaired at ayproximately pis 4. To hameul offects were noted at lesser concentrations altho chlorosis appeared in the solutions wich had pit values of 6 or more due to the insolubility of the 1ron.

Jones and shive ( 21 ) used Insoluble ferric phosphate and soluble forrous sulphate as sources of iron in whive's three aclt solution, $R_{5} \mathrm{C}_{2}$ of 1.75 atmosphere $(44)$, in which Faxquil wheat was grown. The iron vas supplied in 
anounts varylng from 0.01 milligram to 5,00 milligrams per 11ter of solution. Tho solutions were renewed twice week1y for a pertod of ninety days. In the ferric phosphnte series more or less chlorosis appenred which could be easlly raredied by the use of ferrous sulphate, rhere was no chlorosis in the ferrous oulphato series but toxic effects wore apparent at higher concontratlons. The highest yield of plents in the ferric phosphate seriesoccurred vith 2.00 milligrame of lron per Ilter of solution and in the Perrous sulphate series with 0.75 milligram of iron pex llter of solution. This shows that not only the form of iron but the availabllity and anount is of utnost inportance $f \circ$ good plant growth.

tharsh and Shive ( 26 ) used four forms of iron in their strulies on the relation of the growth of soybeans to the amount and form of iron in several types of solutions. They conclided that ferric tartrate was the nost efflciont of the four forns.

留卒th six types of salt solution cultures, Cerlcke (12) grew wheat seedilngs successfully for four weeks, by rotating the plant in dally succession from a one-salt solution to another witnin each type. He found that seadings grown one ay in $\mathrm{KMO}_{3}$ solution, the second day placed in $\mathrm{MLPO}_{4}$ solution, and the thint in CasO $\mathrm{H}_{4}$, were 
$-22-$

almost as large as those frown in tho complete nutrient solution of ali types. lis observed that larger plants were produce l in those types of solutions in which $\mathrm{N}_{\mathrm{B}} \mathrm{FO}_{4}$ and $\mathrm{rmO}_{3}$ were included. Tie states that $1 \mathrm{f}$ s nutrient colaion is a poor medium for plant growth because of a larger proportion of one son, it should be luyroved by tide adalbion of case other ion of opposite chare, even though this be added in the form of alt that would also ald more of the iron already in excess." 
Assindlation of Amonic and Nitric Mitrogen

In experiments with wheat, Fice, motard, corr, and flax plants grown in liquid cultures under conditions which excluded nitrification, pantanelli and Severin (35) concluded theit amonic nitrogen has a coefficient of utilization for the forration of orgonic nitrogenous cospounds superior to that of nitrate nitrozen. They (36) Nuther concluse rThat armoniacal nitrogen has a potential nutritive value for plants superior to that of nitrates, but the full expression of that higher value is coscititioned upon (1) slow absorption of the armonitu cation by the roots, (2) about equal absorption of the corresponding anion, and (3) the possession of a nutritive value by the anion itself."

Thtchinson and wlier ( 16 ) after carefully revieving much of the literature relative to investigations on the assinilation of araomia by plants sumarized the results in these words: "The resulte of Cifflths arxl líze secm to prove conclualvely that beans and raize assimilate armoniun salts as readily as nitrates. The bane may bo sale of kossovitsch's experiments wth peas, for although sterillation was imperiecty maintained, nftrifying organisms ware completely excluded. Breal's 
results may also be consldered to esteblish the utilization of amonia (by pea anoua). The results obtained by pitsch, ilintz, Cerloch and Fogel, and rriger indlcate that vorious plants exployed are eblo to gron in abaence of nitrate - not vith absolute certainty as regards muntz's experiments - but fail to prove that amonia wes the sole sourco of nitrogen."

Priantschntakov ( 39 ) critically reviews the 11teratire on the comparative value of amonia, nitrate, and nitrogen as nutrients for higiner planta. One of the inportant factors is piryslologleal acidity caused by the absomption of the emsonium lon of amontum salts. In his experiments in wich physlological acidty or initial alkalinity are correctly set aside by neutralization he Found that the plant $1 \mathrm{~s}$ able to take up amnonia quicker and convert it into organte aterials, than oceurs by the addition of nitrates. In experiments vith constant1y changine nutrient solutions he states that We thare fully tise oplaion that the increase of armonia in the solution, lteelf in a neutral forn, Eny not exceed certain I. Imito without infury to the plant and that the Iinito for amgonis are lower than for nitratas. Using amonium nitrate as the source for nitrogen he found that plants absorbed the armontum fon quickex than the nftrate fon and that the salt was physiolowically acid 
and increased the utilization of difficultly soluble phosphates by plants. Ho alvo found that manitu bicarbonte, under nearly neutral condition by padsing carbon dioxide through tise solution, to be the best form for introducing amonia to planta.

prianischnition shows that nitritos in weals solutione congtitute good source of nitrogen for higher plants. But an Linerease of the hürogen-1on concentration of the solution Increases the injurious effect of the nitrite and causea tile apsearance of armonia in the solution and acconpanies the torlc action of tha nitrites on plant growth. A defluiency of carbohylurates increases the senstivenes of plants to nitrites.

Using the method of elowing solutions in sumt cul-

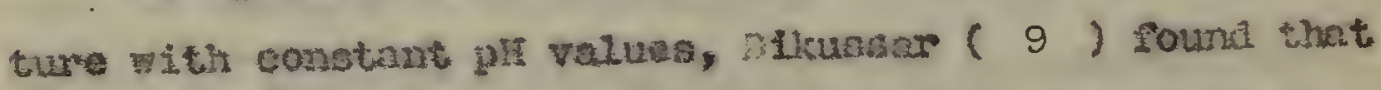
fistrate nitrogen is superior at pI 5.5 , but with pII 7.0 antronita is experior, that the calcium content is always Iower with armona than with nitrites or nitrates with com as the plant indicator". Rewults also indleste that increases in the hycrogen-ion concentration also increases the ash content of tixe plant regardiess of the fors of nitrogen used.

In the case of suger beets the sulphate of armonis at pll 7.0 was more efrective than at pil 5.5. He wugtents that in order to compre the effect of amonia with that 
of nitrates it io nocessury to have a higher concentration of magnesilm, calcium, and potassiun in the nutrient solution for anworia, because armonia hinders the absorption of these basic elements.

pirschle ( 37 ) compared flowing culture solutions with constant pir values with cultures which were not changed and found that calelum nitrate was superior to sulphate of amonia with the unchanged cultures. But with flowing cultures sulphate of amonia proved superior to calcius nitrato at pH 6.0 but infertor at $p$ II 4.5 and 7.5.

In another Linvestieation pirschle ( 38 ) found tint corn and peas were able to absorb nitrogen fron uree as wall in sterile as in non-sterile cultures. This crpacity of the plants to dccompose urea to andonium carbonate is aue to the enzyne urease. He states that aranoniu carbonate is formed, before the nitrogen from urea is absorbet, is proved by an increase of pII in the culture solution with urea.

the carboivarate content of the plant plays an inportant rolo in the assimilation of amonia. rrianiocinikov obseryed that the higher the carbohydrate content of the plant the more dumonic nitrogen can be absorbed by the plants, and the amonia is quickly transformed by the plants to andis under formation of asparagin and Elutandn. 
The results and observations of wevlus ( 28) show that the effect of anmoniun alts of strong nelds is dependent on the hylrogen-1on concentration of the culture solution. In neutral to alkaline reactions the esmontum salts cause an apparent toxic effect. The haraful inMuence of amonium salto increases vith annoniun concentration and decreasing hyirogen-ion concontration. Other unfavorable factors, wheh as light deflelency, Iron defletency, and so forth causes an increase in the toxic effect of the amonlum salts. The enmonium salts, however, are as effective as the alkaline mitrates with the renge of pll 5.3 to 5.6. If the pir value of the culture solution does not fall below 3.6 all Infuries, which are observed in the presence of amonim sults, are to be ascxibed not to phystological a eldity but to their basic constituerst.

Fron a series of experinents with the corn plent Hevius ( 29 ) shows the then amonia salts of strong aclds are presented to the corn plant as sources of nitrogen, the basic constituent of thege salts disappears from the solution with increasing speed in direct proportion as the pH value of the solution increasea. IIs results shor that the reaction is one of the most inportant factors which deterrines to what extent the nitrogen of ammonia ealts 16 absorbed by the roots, and 
that the dependence of the nitrogen absorption stands in causative connection with the derree of the hydrolytic dissociation of the amoonia salt in the culture solution. The formation of adparagin, within the plant, upon the absorption of nitrogen f rom amoniun salto, according to wevius, is now assuned to be a stags of detoxication of amonie. The com plants are able to counteract the toxicity of the penetrated amonia by organic acids, the anino acids and its amides. He states that the $\mathrm{sit}_{4} \mathrm{nI}-$ tromen penetretes into the root collo as $\mathrm{m}_{3}$ molecules and probably as mil by organic acids. The production of the organic ecida 16 stimulated by the peretrated amonla and theso acids can oxiginate only in carbon netabolian. Mevius concludes that the wrmoniun nitrate salt is physiologically axphoteric. The physlologieal a cldity, which appears under conditions favorable for carbon assimilation, can be changed to physiological alkalinity by a considerable decresse of the 11lumination; that the amonium nitrogen absortion in the presence of amonius nitrate as a source of nitrogen has to mun independently from the nitrate nitrogen absorption. 
Results of the invegtigations by Jones and Mkinner(20) on the absorption of nitragen from culture solutions show that in the case of soy bean plants both forms of nitrogen are absorbed. At the three weeks period of growth much larger quantities of the $\mathrm{mi}_{4}$ + form than the $\mathrm{HO}_{3}-$ fors was used, but at the rive weezs period of growth the reverse condition was mifested. Wth com plants the results indicate that absolute absorption of nitrogen in the $\mathrm{min}^{+}$+ form took place at a uniform rate, but that the aboorption of nitrogen as $\mathrm{wO}_{3}-1$ af afected by age, vigor, and growth rate of the plant. (45)

shivelof the Hew Jersey ixperiment Station, working on the absorption of $\mathrm{NR}_{4}+$ and $2 \mathrm{KO}_{3}$ - forms of nitrogen with several specles of plants, found thet there was a high absoption rate of $\mathrm{HL}_{\mathrm{k}}+$ form of nitrogen during the early grovth prases and rolatively very low absorption rate furing the late Erowth parses; that there was a low absorption rate of $10_{3}$ - form of nitrogen during the early growth phases and a gradual upward slope cluming the late growth phases. In the case of oats, however, the $\mathrm{nl}_{4}+$ absorption abruptly increases at the tilloring state and the $\mathrm{NO}_{3}$ - absorption decraases indeating athat young active growing tisaue cemands the ky + form of nitrogen. Te also found that the total absorption rate, when the two foras of nitrogen are prosent, Increased grodually until 
the reproduction phase of development. Iater ( 46 ) he found that during the mature development and seed forming phase the nitrate form was absorbed the more rapldiy. He states ( 47 ) that the "Resulte of this 1nvestigation clearly show that nitrogen absorbed by the plant as $\mathrm{mh}_{4}$ is much more closely asoociated with the synthesis of organic nitrogen compounds by the plant than is the absorption as $10_{3}-$. This is indicated by the fact that culture solutions with relatively high proportions of nitrorgen no $m 4$ t and 10 proportions of $\mathrm{m}_{3}$ - invariably proAuced plants which were high in both soluble end total organle nitrogen," then the proportions were reverged plants were found to be Low in soluble and tothl organic nitrogen. During later stages of growth high proportions of $\mathrm{min}_{4}$ + nitrogen in cultures showed accumulation of $\mathrm{mi}_{4}{ }^{+}$ In tissues of ouder plants. This becomes so pronounced in the plants grown in culture solutions with relatively high proportions of $\mathrm{WH}_{4}+$ and low proportlons of $100_{3}$ - that toxielty results and the egrowth rates are markedly retarded during the in ter stages of development, thile durling the early stages of grovth these solutions invarlaliy produced better plants than did those with low proportions of $\mathrm{mi}_{4^{+}}$ani high proportions of $\mathrm{NO}_{3}$ - but otherwise the same."

Above $25^{\circ} \mathrm{C}$ any changel in temperature caused very little variation upon the hourly absorption rates of ni- 
trogen in the form of $1 \mathrm{H}_{4}+$ and $1 \mathrm{k}_{3}$ - but below $25^{\circ} \mathrm{C}$ the absorption rate of the NIh+ Ion was mach moro affected than that of the No3-10x. 
In a series of experinents with com, cotton, and wheat seedings grown in solution, sand, and soll cultures with varlous anounts of $\mathrm{NH}_{4}$-nitrogen $\mathrm{NO}_{3}-\mathrm{nitrogen}$, and the two formo in combination raftel ( 30 ) studied the absoption of nitrogen at alfferent stares of growth. Fle states that all experlments gave similar resulto. only the work on cotton is reported. His results show that

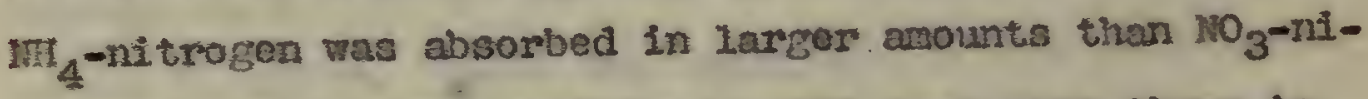
trogen by the young seedlings unt11 they were three to Iive weeks o1d, after which time wore No $_{3}-n 1$ trogen was used. Larre amounts of both forms were absorbed by tho plants when four to elgit weeks old. The absorption of the $m_{4}$-nitrogen increased as the aclalty of the culture solution decreased. Hirete nitrogen absorption, hovever, was only sifghtly affected by the reaction of the nutrient solution. Greatest growth and frulting, and groatcat tetal. nItrogen absomption occurred when both forms of nitrogen were present in the cultures.

raftel aloo presents data wich indicate that the nitrogen in the seed is avallable to the sprouts and young seedingo in the amoniur fors: 


\section{Discussion of Reaulta}

Rice

Duming the firat rev days following the placing of secdings in nutrient solutions, in which the weather vas cloudy, it was noted that the rice seedings becane light green in color. Isatar the condition of the seedlings revealed marked symptons of chlorosis especially martsed in the seedings receiving the organic nitrogen from urea. The iron apply was lomediately increased from $5 \mathrm{cc}$ of a $0.1 \mathrm{~s}$ solution of ferric potassium tartiate such as used on the wheat cultures, to an equal amount of a 0.5 solution. The control cultures were first to respond followed by the combined nitrogencultures. The cultures recelving nitrogen from amonium sulphate as well as those receiving nitrate nitrogan responded slowly, but the solutions contalning urea never recovered Trom this chlorotic condition.

The two sories of rice seedlings which were placed In solution on "arch 20 , recelved $5 \mathrm{cc}$. of a 0.55 solution of ferric potassium tartate as the source of iron, grew very well. Only the urea snd nitrate of aoda cultures showed slight symptomo of chlorosis as indicated by the sllghtly lighter green color of the younger growing leaves. The older leaves were of noral green color. 
The leaves of the other cultures receiving nitrogen from amoniun sulfate alone or in combination vith nitrate of soda ohowed a dark green oblor characteristic of plants receiving nitrogen in the ananonium form.

The plants supplied with urea did not grow as well as the planta which received other coms of nitroren. Due to the hydrolysis of urea during hot weather it was necessary to change the treatment of these cultures. Throughout the remainder of the experinents these plants were placed into a golution of urea for one day and then Into the wineral mutrient solution the second day sinliar to the zethod described by Gericke (12). The plants were lighter green in color whlch wao especially manfested on the younger leaves. The roots were of a normal healthy strav color.

The plants receiving nitrates altho thoy did not grow as well as those cupplied with urea during the first stage were larger and more erect during later fron th. The leaves were more erect and alightly dawer in color compered with plants supplied with urea. Root srowth appeared to be norwal.

The plants grown with armonium salts alone of conbined with nitrates were normal in top growth duxing the first two wonthe except for the atriking dark green color of the leaves. The roots, however, were duriter in color 
and shorter in proportion to the arrsonic nitrogen presented to the plants. The plants receiving only amonium falts shomed slight deterioration in the development of the young roots. The tips of the white roots developing from the crown darkened in color and later bocame bromn. h This condition became more maricod vhen the nitrogen supply was doubled during the thint nonth of growth. At this time the top grow was checked and the plants shoved a weakened condition as irdicated by the arooping of the leaves. This character of growth is well illustrated by platea I and II.

The leaves of the control cultures were apparently of normal color, but the roots were very lons and thin indicating nitrogen deficiency.

The data on hydrogen Ion concentration are recorded ow In tables 1,2 and 3 . The nitrate nitrogen cultures thar a definite increase in pir values toward alkalinity. on the other hand the cultures recelving armonium salts show cecreasing of values from the inttal range of pll 0.4 60 6.6. This was most noticeable in the solution shich contalned only amonium sulphates. The cultures supplied with both the salts of armonia and nitrate were slightly Lower in hydrogen ion concentration. Mhis indicstes that there was reater absorption of the asmoniun Ion than the nitrate lon in these solutions. 


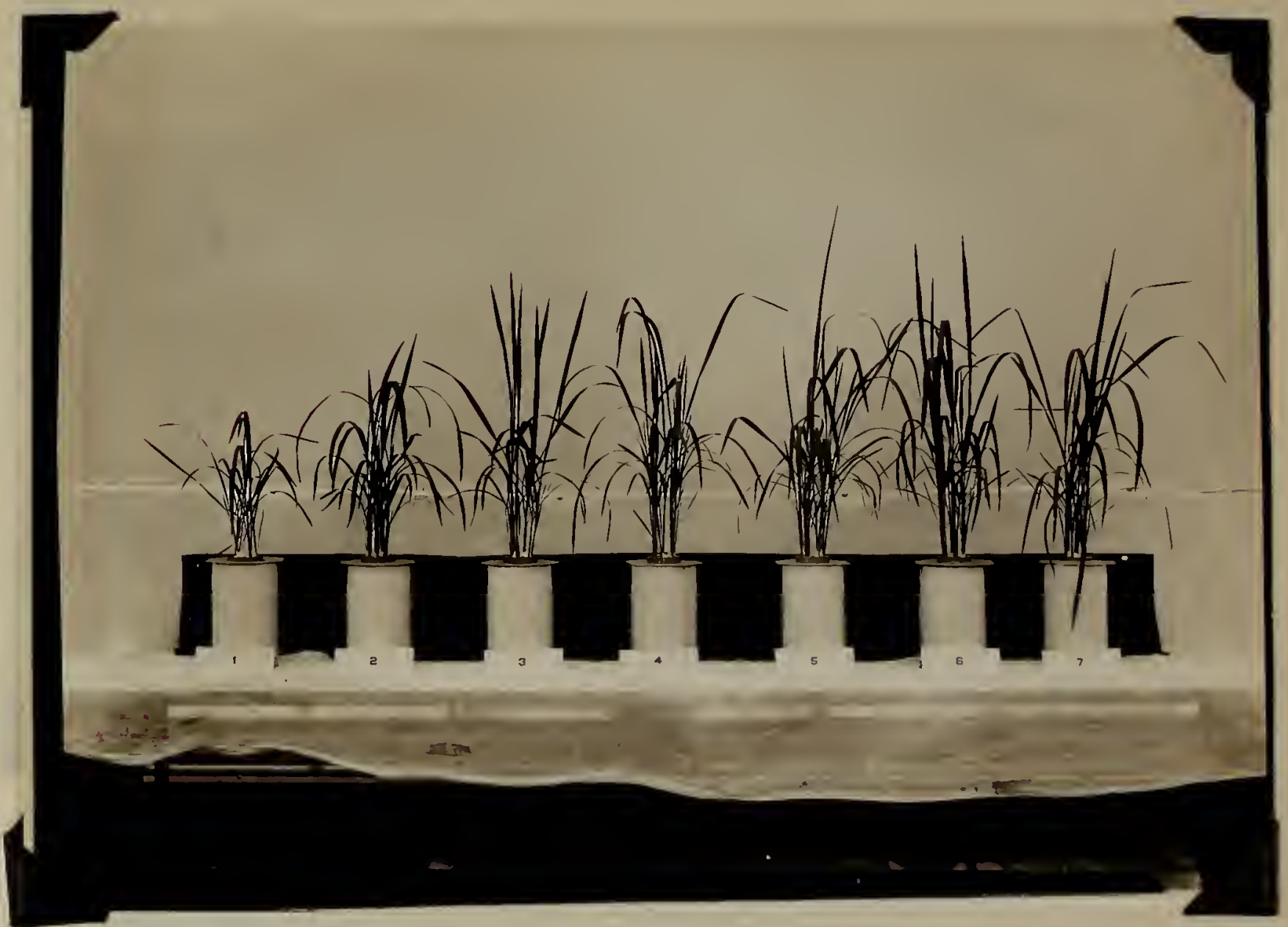

Plate I. Rice Plants, aproximately two months old, in the second stage of growth.

1. Control

2. Urea

3. $\mathrm{NaNO}_{3}$

4. $\left(\mathrm{min}_{4}\right)_{2} \mathrm{SO}_{2}$

5. ManO $\left(\mathrm{WH}_{4}\right)_{2} \mathrm{SO}_{4}-$ ) of nitrogen

6. $\mathrm{KaNO}_{3}-\cdots \mathrm{MO}_{2}-\cdots$ )

" ratio of $2: 2$ perts of nitrogen $\left.(\text { (nt4 })_{2} \mathrm{SO}_{4--}\right)$ of nitrogen 


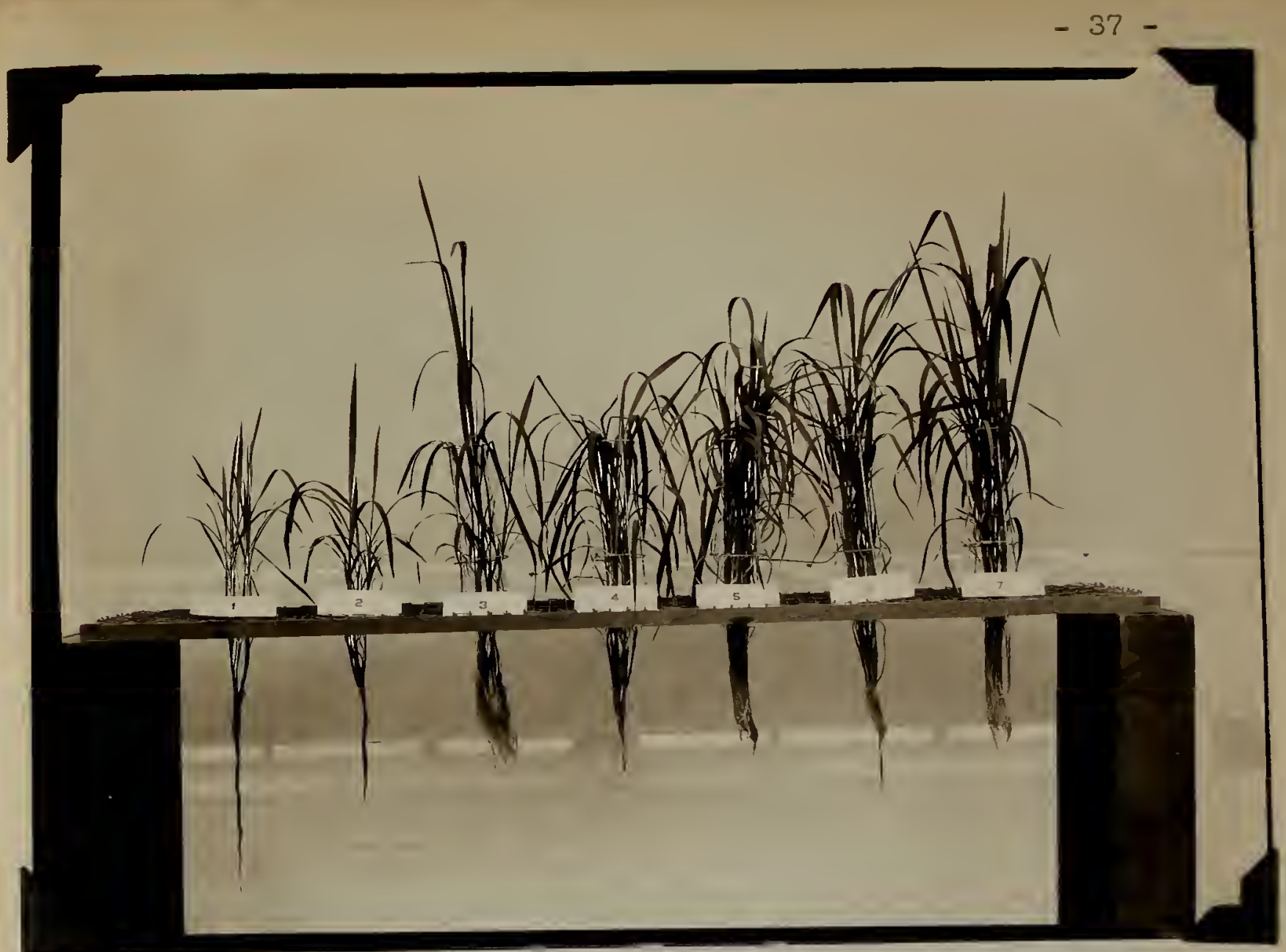

pate II. Bice plants, two anths and twenty-three days 010, in the third stage of growth.

\section{Control}

2. Ures

3. $\operatorname{tart} 3$

4. $\lim _{1} / 2=4$

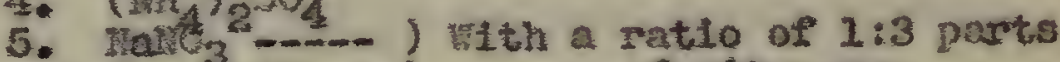

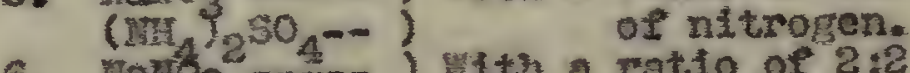

6. rallo $3-\tau^{4}$ ) with a ratto of $2: 2$ parts

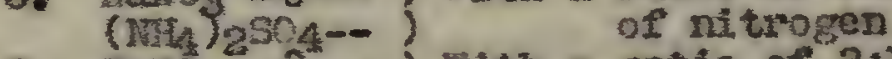

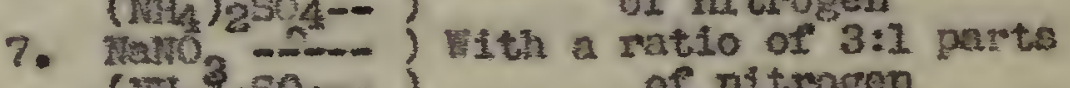
$\left(\mathrm{mL}_{4} \mathrm{~S}_{2} \mathrm{SO}_{4}--\right)$ of nitrogen 
The number of plant culms is indicative of the response of the plant to its nutrient environsent. From the ata glven in table 4 it is noted that tie control cultures which vere supjlied with no nitron produced slightly more than one culm per pinnt. It is evident that the plarts which received combined nitrogen ani compare favorably wh anonium sulphate in the rirst stage of frowth, are sugerior to the nitrates at all stares of growth in the number of plant eulas moducech. Thebe plants also produced a larger nuber of plant culms at the second and third stage of grovth than the plants mhich recelved only atmonium sulphate. The plants supplied with organte nitrogen produced more culms than the plants vhich graw in the presence of sodiun nitrate at tite first stage. The data aløo reveal that this group In the second stage of growth produced the larest number of culms.

The ylelds in ary matter produced by the various forms of nitrogen supplied to the plants are given in tables 5, 6, and 7. It can be seen that the differmees between the means in table 5 are not elgniffeant except in the case of control and nitrate of bods groups which are very low. From this data it apyears that the rice seedings are able to assinilate nitrle nitrogen as vell as organic nitrogen but prefors the latter to the former. 
In the second stages of erowth according to table 6 It is noted that there is a progressive increase in total yield wich is in direct proportion as the anount of nitric/ Incrased in the combined nitrogen culturas. The yields of the sodiua nitrate and urea groups show that these foms of nitrogen are not as effective as those grown with araniun sulphate. The plants grown with the combined nitrate and amoniu salts produced the highest total yield as expressed in ory velght, indicating that this form is the nost epective.

The results for the third stage as recorded in table 7 show wowewhat different results. At this period the plants recalved twice as meh nitrogen as during the two preceeding periods. Since the yields of godium nitwate are grester than the amonium exlphate and the 3 to 1 proportion it nay be assused that the concentration of amonium salts was too high far good Brovth. The growth of the amoniun sulphate group was checised, the leaves began to droop indlcating a weakened condftion, the roots becanc brom, slimy and aecomposed. Thove symptons indicate thet arononiun anlts at this concentration are toxic to rice plants. The ylelas of the 3 to 1 proportion of the combined nitric and amonic nitrogen cultures show that the nltrogen in this proportion 15 the most erfective for growing rice.

As stated previously in the intooduction plants are able to absorb either ormutc or inomganc forms of ni- 
trogen, bat may not be able to assimilate all of the accuralated nitrogen in the plart. Thie is clearly indicated by the ata in tables $s, 9$, and 10 . Considering the nitrogan 'rections at the first stage of grovth it was found that the anounts of amonic ar nitrate nitrogen increase in proportion as the amounts presented to the plants in the fom of amonium or nirate salts are increased. The plants which were grown with sodiun niwate contained the largest anount of toakl inargante nitrogen. The amounts of organic as well as total nitrogen increased from nitrato of soda, urea, to armonium sulphate respectively, In direct proportion as the amounts of gronium salts were increased. This shows that the andoniun form of nitrozen in nore effective timn the nitrate or organic sources of nitrogen for young sice sectilng. .

The data given in table 9 show that the plants grown with armonfun sulphate contained the anallest amount of inowgane nitrogen, the control excepted, and produced the largest amount of total organic nitrogen. The superiority a urea over nitrate of soda is also evident. But those plants receiving comined irorganlc nitrogen contalned more organic and total nitrogen than those plante grown with nitrate of sola or urea.

That the axaunt of nitrogen presonted to tho plants during the third month was considerably increased is- 
Indicated by the date in table 10 which show lasse amounts of inorgenic or unassinlated nitrogen for the - ix groups of plants. Hnder these conditions amonium sulphate compares favorably with nitrate of sola, but the plants grown with the combined inorganic nitrogen contain the laxger snounts of inorganlc, organlc, and total nitrogen. 
heat

The wheat seedlings during the first month of growth received only 5 ca. of $0.1 \%$ solution of rerric potassium tartiate as the soisrce of Iron and showed no chlorosis. If wheat and rice plents can be compared it is very evident that the rice plents manifest a groater need for available iron.

The plants grown with organic nitrogen were nornal In every respect until the urea hydrolized during the second month of growth. pecompostion was noticed upon the lower portion of roots. This decorrosed protein was cut away and the plants during the remalnier of the oxperinent were trested as desuribed above for rice seed1ings. Inder these severe conditions the grovth during the thind month was checked.

The plante supplied with nitrates grew normily and vigorously from the beginning of the experimont but the growth was sosewhat uneven during the latter part of the growing perlod. The color of the le aves wha nomal and nealthy. The roots were of the charactarlstic graylsh white color unt11 fungi appeared curing late grovth. The plants in this group and in two of the groupa receiving the combined inorganic nitrogen were the only plants 
to head (see plate III).

The plants supplied with annonius sulphate did not grow well after the first few dayn. Later the following symptoms appeared. The tips of some of the leaves twistad anc dried uy. The lower leaves dried up, aled, and then tumed yellow. The upper leaves lacked the turgor characteristic of plants receivine nitrates. The roots tumed from a grayish white to a dark brown, becane sling and accorposed. Yew roots apeared near the crown. A rew days later these in turn changed in a sanner similar to the indtial root system, and fungous growth a pjeored. other nev sots apoared and these slovly deteriorated until sinaly the plants aled. These eymptors indeate toxiclty and axe simliax to those describod by Beaunont ( 5 ) for toxicity in tobacon plants. The growing loaves of this group on planto had a very dark green color thich a ppeared to be characteriatic of all tire planto receiving ammonium sulphate as the ource of nitrogen.

The plants supplied with both forma of inosganic nitrogen grev bottor at first than those whici recelved only one form of nitrogen. Then the symptoms, such as descrilied above, appesred on those plants which received the largest proportion of amoniu alto and thers followed by the plants with lesser projortions of amonlum alts. This condition is clearly pletured in plate IIt. 


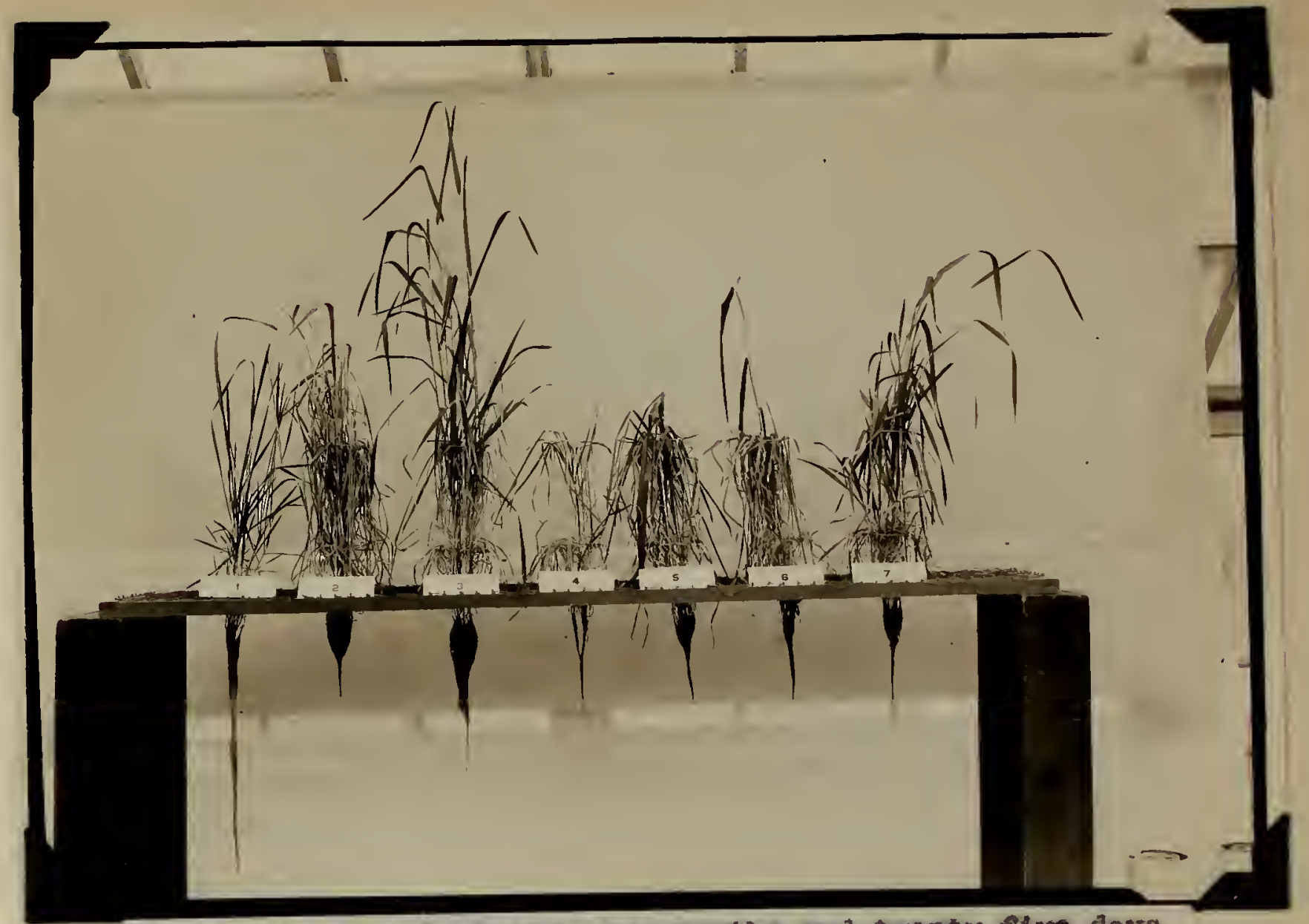

Plate II. Wheat Planto, two months and twenty Ive days old, in the thind stage of grovth.

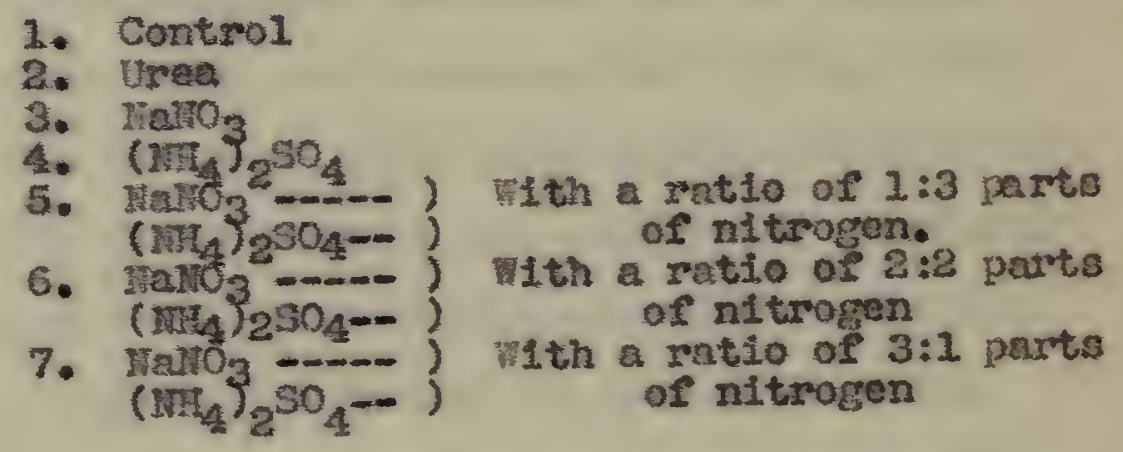


The plants supplied wth the 3 to 1 proportion of nitrates and armonim salts grew very vigorously throughout the period or the experinent, but the plarks were not as erect as those supplied with nitrates.

The cata on tive lyyrogen ion reaction a presentod in trbles 1i, 12, and 13 indicate chonges which are sintlar to those wich scoureed vith rice plants, but the pll values of the comblned nitrogen and tive andoniun sulphate cultures sre not as Iow. This my indicate proferential absorption of the nitrate ion.

The effect of the various forms of nitiogen upon the production of plant culns is brought oub by the data in teble 14. It is olsemed that the rumber of culns from plents supglied with amonlun sulphate is de:idely less than from plants roceiving any other forn of nitrogru. the plants grown with urea produced the raxinum nuber of eulins. The muber of culns from plants supplied with sodium nitrate compares favonably with those grown whth diferent moportions of corbinet nitrogen in the first and accona stages of growth and is reater than tho I to $3 \mathrm{and} 2$ to 2 proportions of the thind otage. The 3 to 1 ratio produced the second lirgest number of plant curnas.

From the atatia on yields of dry natter as ohown in tables 15,16 , and 17 the mean of the dry weights of tho 
plants produced by the various anurees of nitrogen are statistically sireifleant. The ylelds of the combined nitroren cultures increased progressively as the ratto of nitric nitrogen to amonic nitrogen increased. The three to one proportion gave the largest return durlng the first and third stages of growth and the ammoniun sulphate lot gave the anllest yield of plants in every case, except the control culture of the pirst staye. This relationship holis also for the dry weights of rooto and tops. The urea source of nitrogen was more effective than nitrate of sode in dry satter produced.

In table 16 tive ylelds from ures were the in rest with nitrate of soda next. But in table 17 the 3 to 1 proportion of combined nitrogen gave the laxgest yleld followed by nitrate of soda. The outstanding fact presented by these data is the very ponr yielas fran tho anmonium sulphate cultures indicating that garsenfur sulphate as the sole souree of nitrogen is decidely inerrective.

The anounts of amonic nitrogen contalned in the plant increased in proportion as the amounts gresented to tho plants sre increased is shown fros the clats on the nitrogen fractions in tables 13,19 , and 20 . This relationship is aløo true for nitrie nitrogen except for the 3 to 1 proportion where the amount is a trifle 
higher in the first stage and much higher in the third stage of grouth. The anounts of inorganic nitrogen for the uren and control cultures is very sanll as would be expected. A corgaritson of tho artountis of anenonic nitrogen wh nftric nitrogen in table 18 indicates that the annonfum form is assimilated in larger amounts than the nitrie nitrogen. These data sloo ohow that the greatest anount of organic nitrogen was produced during the îrst stage of growth. The largest amourts of inorgantc nitrogen vere found in the whent planto it the thind stare of growth, anounting to more than forty percent of the total ntrogen contert. Another striking fact is the anount of anonic nitrogen present as shown in tables 10 and 20 which closely correlates with the degree of toxiclty manfested by plants from these respective groups. 


\section{Sunenary and Conclusions}

Tris thesis gives the results of an investigation on the effect of aone forss of nutrogen on the gruwth and nittogen content of rice and wheat plants grom in solution cultures. The selts used as sources of nitrogen were urea, socius nitrate, and anmoniun sulyonte. Combinations of sodium nitrate and amonium sulphate were alco used in thre alfer nt proportlons of nitrogen. These three proportions of nitric to amonic ntrogen mere in the ratlo of 1 to 3,2 to 2 , and 3 to 1 respactively. The Vintula variety of lomland rice and garguis wheat vere grown in a modfied Crone's nutrient solution. Each culture contained six plants and the cultures nere replicated five titas. Control cultures which received no nttrogen were also grown. The cultural solutions were ranewed trice weekly. Data wore secured on the hylirogen fon concentration, nubber of plant culms, yield in ary weter of tops, roots, and total plant material for three states of crovth, which were ap roximately one month, two months, tiwee months in duration. Analyses of the nitrozen fractions vere made on the dry meterialand the arounts of armonic, 
nitric and total nitrogen determined.

The conclualons thay be sumranized as follows:

1. Observations inaicate that rice plants hive a hichther recuirement for avalable Iron than whent plants.

2. The absorption of nitrogen in the nitrate and organic forma Increased the pti values of the mutrient soluthons.

2. The absorption of nitrogen in the asmonitur com deercased the pri values of the nutrient solutions.

4. The absorption of nftrogen from solutions containing different proportions of nitzate and nmonium salte decreased the pll values of the nutrient colutions, but this aecrease was slightly lese than the pII values of the solutions thich received only cmonium salts. In case of whent plants these valueswere comparatively higher.

5. If the character of growth, the number of plant culas produced, and the yield of dxy matter produced, Eay be considered as criteria, then amonium suphate was more effective than nitrate of soda or ures for - rice plante, during the firot and second stages of sowth. In the third state in which the concentrition of ardwonium salts ws doubled mitrate of soda proved more effective.than awoniun or the 1 to 3 proportion of corbined nitrogen except in the number of plant 
culvo produech. For wheat urea and nitrate of soda proved more effective than armonium sulphate at every stage of growth. The 3 to 1 proportion of ankonic and nitric nituogen produce? the largest yield of rice at all throe stares of growtin. This combination also produced the larfest yield of whent during the first and third starea of growth but was surpassed by urea and nitrate of solk at the econd state of Exowth.

6. Armonium sulshate produced symptoms of toxicity on wheat plants during first atoge of growth, which effect was cumulative through tire second and third stages at which times it becase pronounced. The $1: 3$ and $2: 2$ combinitions 3.eo showed symptoms of toxicity in proportion to the anounts of amsonituralts present. The growth of rice in the third state was depreswed by the increased concentration of the amontum selts.

7. In general the amoints of inorcanic nitrogen in the plant Increased in direct proportion as the amounts in the inltial nutrient solutions for both rice and wheat vere increased.

8. The annonium salts produceũ the greatest amount of organic and total nitrogen with nomal rice plants. vith wheat plants the combined salts of amonium culphate and nedium nitrate produced the greatest axount of organic and totel nitrogen during tre first two ctages of growth. The 1 to 3 combination produced the la regest anount of organte 
and total mitwogen in the third otage.

9. When the concentration of the supplied salta was doubled the groatest anount of oryanic and total nitrogen carae fron the comblnet nt trogen cultures for both rice and wheat plart. 


\section{Bibliography}

2. Aso, the

On the physiological influence of manganese corpounds on plants. Bul. Col. of Agr. Japan $6: 13103.1502$.

2. Bartholomew, R. nefect on sol1 reaction of nitrogenous fertilizers under anaerobic conditions of rice production. \$our. A,. Soc. Agron. 20:1305-15. 1928.

3.

The availability of nitrogenous fertilizers to rice. So11 science 28:85-104. 1929.

4. Reeumont, A, B., and Larsinos, G. J. ilater culture technic for studies in tobacco nutrition. Jour. An. Soc. Agron. 21:150-155. 1929.

5. Beaumont, $A, B$. Toxiclty of anoniu compounds for tobacco. To be published in the procecdings of the International Soil Congress. 1931.

6. Dalikhara, G., and Iransele, $T$. on the behavior of nitrates to paday solls. Bul. Imp. Cent. Agr. Bxp. Station Japan 1:1-36. 1907.

7. Davi son, Jehiel, and Leclerc, J. A. Refect of colium nitrate applied at different stages of gronth on the yield, composition, and quality of whoat. Jour. An. Soc. Agron. 9:145-154. 1917. 
8. Devidson, Jehiel

The erfect of nitrates applied at different stages of growth on the yield, conposition and queifty of wheat. Jour. Am. Soc. Agron. 14:118-122. 1022.

9. Olkussar, I. G.

Die fiskung des Amoniumalfats und des Salpetors auf die tntwicilung von zuckurriben und kals in Abhäglgseit von der chem ischen Zueanensetzung der Jahriosung. Landw Jahrb $72: 791930$.

10. Espino, R. B.

Sone aspects of the salt regulrement of young rice plants. Philippine kag. and Jour of sc. 15:455-523.

11. Geriche, 籍.

plant food regulresent of rice. Soll Science 29:2082191930.

22.

On physiological balance in nutrient golutions for plant cultures. An. Jour. of kotany 0:180-182. 1922.

13. Gile, P, l., and Carrero, Jै. 0 . Absorption of nutrients as affected by the number of roots sup lled vith the nutrient. Jour. Agr. Res. $0: 73-95 . \quad 1927$.

14.

Assinilation of colloldal iron by rec. Jour. Agr. Res. 3:205-10. 1914 .

15.

Assimilation of iron by rice fros certain nutrient solutions. Jour. Agr. Kes. 7:503-52s. 1914. 


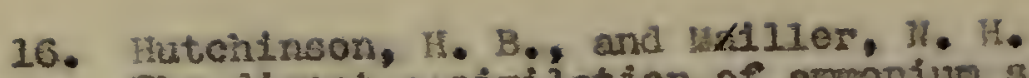

The direct assimilation of amoniun salts by plants. Jour. Agr. Sc. 3:179-194, 1909.

17. Jacobson, H. G. M. Changes in hydrogen ion concentzation in nutrient solutions: is cultures vitis rice. Jour. An. Soc. Arron. 17:583-86. 1925.

18. Change in hyarogen ion concentration in nutrient solutions: in cultures with wheat. Jour. Mr. Soc. Agron. $17: 577-583.1925$.

19. Janssen, George, and 'Tetzger, H. Prinsformation of nitrogen in rice soil. Jour. Am. 5oc. igron. 20:459-76.

20. Jones, C. D., and Skinner, 5. T. Absorption of nitrogen from culture solutions bs plants. Few Jersey Agr. 5xp. Report - $1926 \mathrm{pp}$. $260-355.1326$.

21. Jones, tinus, F., and Shrve, John The effect of ammoniun wulphate upon plants in nutrient solutions sup lied with ferric phosphate and fersous sulphate as sources of iron. Jous. ing. Res. 21:701-728. 1921.

22. Keliner, O. chemische Studiem über dis lé scultur. Landw Ver's. Stat. 30:18-32. 1884.

23. reuner., Kozal, $y_{\text {, }}$ Norl, Y, and Tagaoka, ". Wanuring experiments with paday rice. Col. Ar. Tokyo Imp. Jntv. 1:N10.9 pp. 149. 
24. Kelly, พ. P.

The assinilation of nitrogen by rice. liawailan ster. Exp. Sta. Bu1. 24. 1011.

25. Loew,,$\ldots$ and Sawa,. on tise action of manganese compounds on plants. Bul. Col. hgr. Jagan 5:161. 1002-03.

26. 粦arsh, R. P.. and snive, J. hajustment of iron supply to reculrement of soybeans In solution cultures. Bot. Caz. 73:1-27. 1025.

27. Motzger, W. H. and Janssen.

Rolation of codium nitrate and cemtaln other nitragen carpiers to the developrent of chloroste in rice. Jour. Agr. Nes. $37: 589-602$. 1028 .

28. Mevius, valter

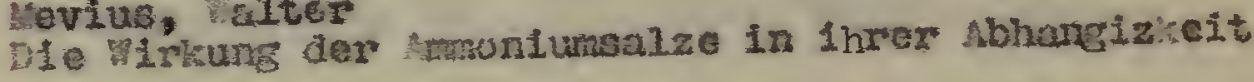
won dex Easerstoplonenzonzentration. Planta $6: 379-455.1928$.

20. TIO von der "usserstefrionenkorzeritration. "lanta 9:1- 1928.

30. Naftel, Javes A. The absorption of andoniun and 'nitrate nitrogen by various plants in different stages of srowth. Jour. Am. soc. Agron. $23: 142-158.1931$.

31. Vagoakta, 栔

on the behavior of the rice plart to nitrate and amonius salts. Wul. Col. AEr* rokyo Imy. Univ. $6.285-334.1004$. 
32.

On the manurial value or calcium cymand. Bul. Col. AgE. Tokyo Imp. Jniv. 6:135-.236. 1904.

33. Olson, Gesrge A.

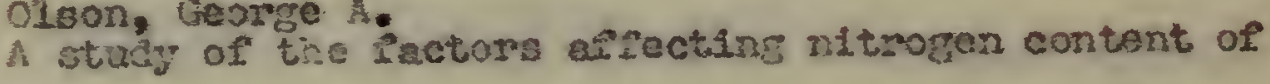
wheat and the changes that occur dundng the development of wheat. Jour. Agr. Reฮ. 24:932-955. 1923.

34. Palisoc, B.

Comsative nutritive values of afferent salte of arsonfur. Philipjine Agr. 17:37-13. 1028.

35. Pantanolli, 5 and coverint, G. tome experinents on the utilization of amonium salts by greon plarts. watu. Sper. Cegr. Ital 43:pg. 449-514 cited in 12xp. Sta. Rec. 22:223. 1510.

36.

Futher exporiments on the utilization of ammonium salts by green plantis. staz. sper. Agr. Ital. 14: no. 11 \& $12 \mathrm{pp} .873-30 \mathrm{~s}$ cited In $\mathrm{F} . \mathrm{s}$. Record 27;634. 1911.

37. pirschle, $K$. Assinilation des Furnstofo durch nöhore Planze Blochentsche Zeitachr 212:460. 1929.

38. Mtrate und Amonsalze als 3tlczstor feguelien fur hohere pelanzen bei Ronstanter ascerstofflonenkonsentration. Planta 9:84. 1929.

39. Prianiechriteov, D. F,

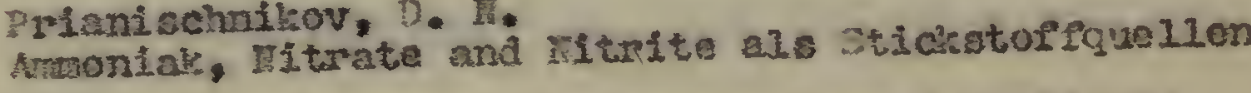
fur hohse pelanzen. In Exgebrnisse der Bilogie, Fister Band 407-444 Jullus Springer, Berlin (translatjon). 1926. 
40.

Zur Frage der Armoniakernahrung der hoheren pelanzon. Blochenische ttschr 207:341- 1329.

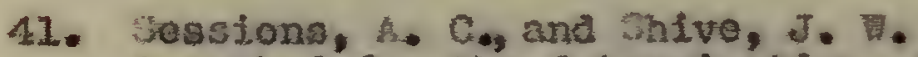

A method for the determination of inorgmic nitrogen In plant extracts. Plant Phys101. 3:499-511. 1928.

42. Seesions, A. C.

A method for the deterrination of inorganic nitrogen in arled plant tiosue. 3oll sc. 22:235-9. 1930.

43. Sewell, c. $_{\text {. }}$

Relation of the wolecular proportions in the nutrient solution to wist growth of wheat. Jour. Agr. Rea. 28:387-93. 1924.

44. Shive, Johs, 些.

A study of physiological balance in mutrient media. Physiol. nes. 1:327-327. 1915.

45.

Keport of Bept. of plant physlology * Mew Jersay Agr. Sxp. ita. Ipt. 1027-pp. 31. 1927.

46.

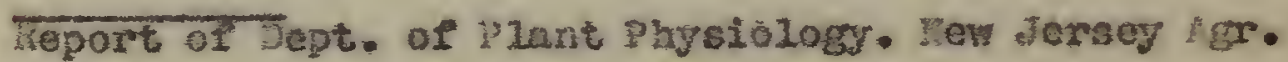
政xp. 5ta. Rpt. 1928 p. 58. 1928.

47.

Roport of Deph. of plant Physlology. Hew Jersey Arx. Rxp. Sta. Rpt. 1929-p. 45. 1929.

48. Tarr, , w, and Foble, S. C. The effect of hydrazen Ion concentration upon the growth of seedinga. Nel. kers. Jxp. Sta. Bul. 131. 1922. 
$-58-$

49. Nottingham, 1. .. A quantitative chemical and physiological study of nutrient ablutions for plant cultures. Physiol. Researches 1:27o. 4-133-245. 1914.

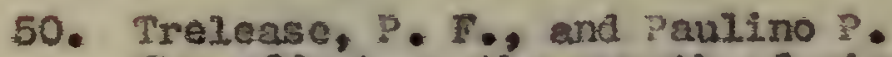
The er rect on the growth of rice of the addition of ammonium and nitrate salts to soil cultures. Philippine Agr. 8:293-313. 1920. 
- 59 -

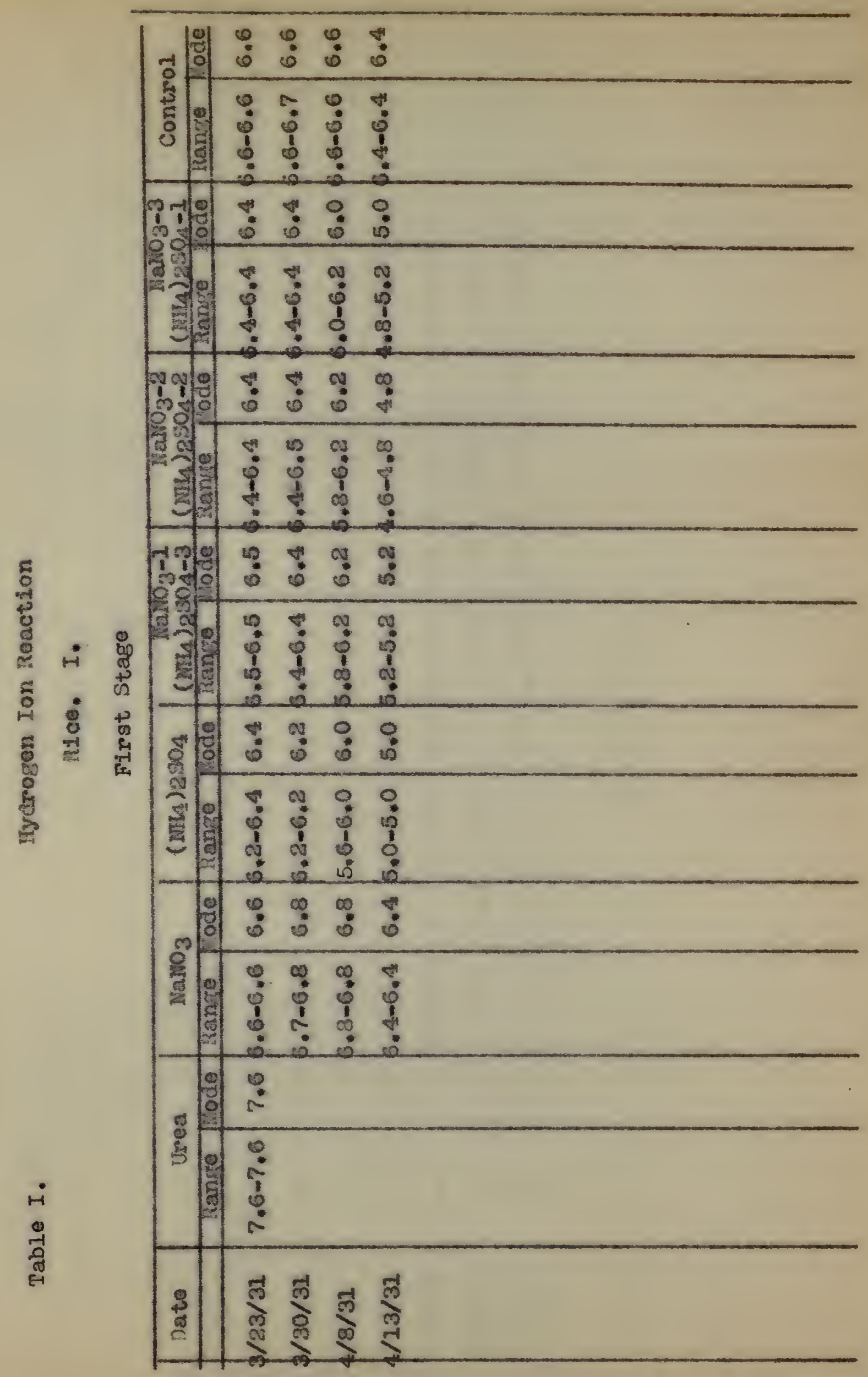




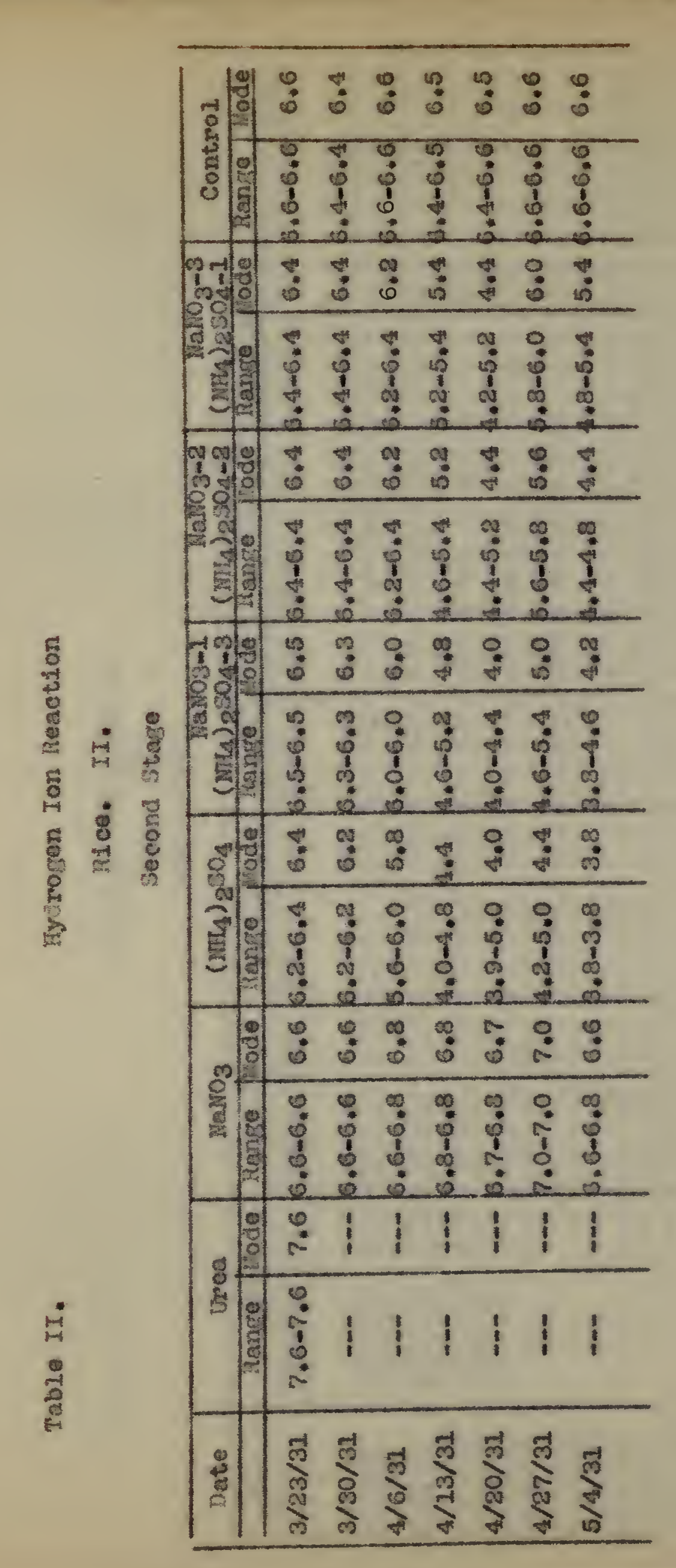




\begin{tabular}{|c|c|c|}
\hline & $\left|\begin{array}{l}0 \\
0 \\
0\end{array}\right|$ & 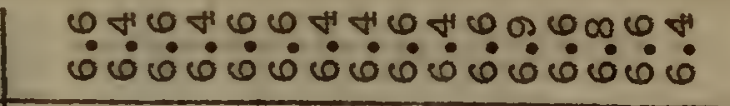 \\
\hline & 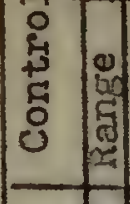 & 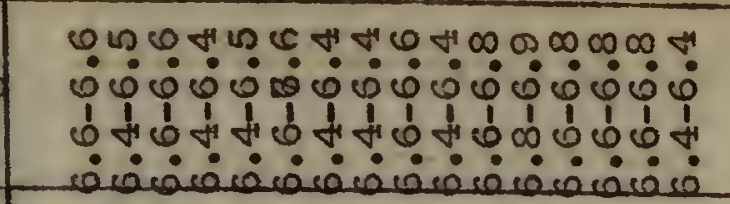 \\
\hline & 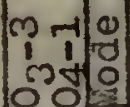 & 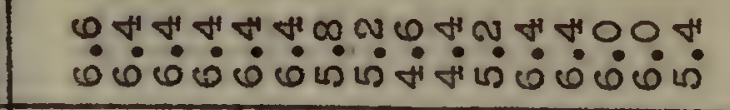 \\
\hline & 起象 & 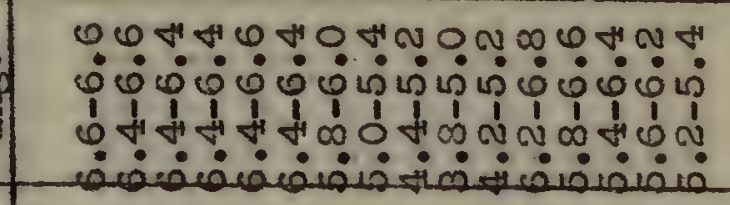 \\
\hline & w v & 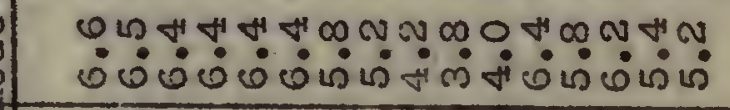 \\
\hline & 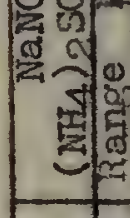 & 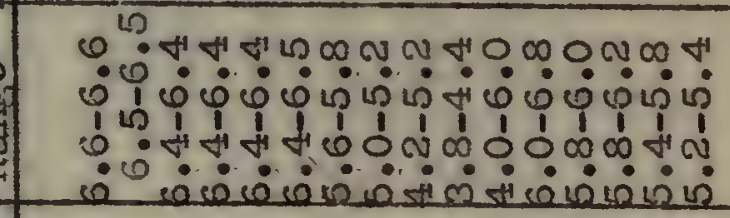 \\
\hline & $\begin{array}{ll}1 & \text { mle } \\
1 & 1 \\
0 & 0\end{array}$ & 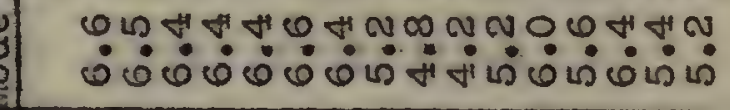 \\
\hline 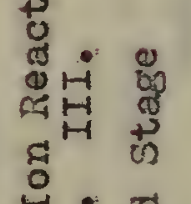 & 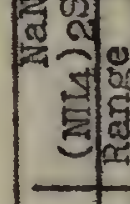 & 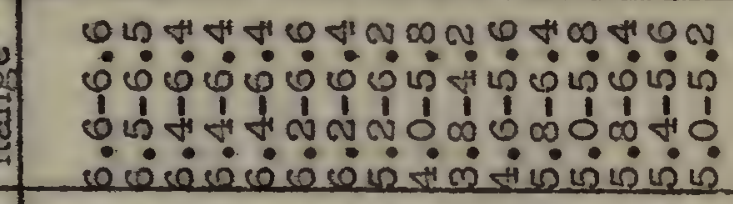 \\
\hline 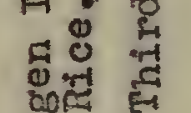 & $0^{4}$ & 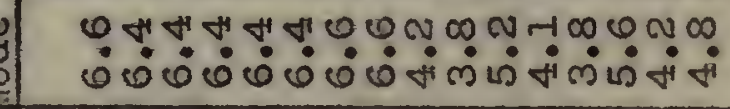 \\
\hline 点 & 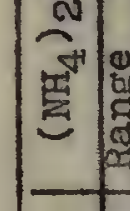 & 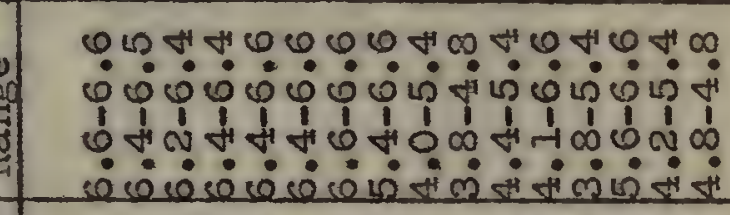 \\
\hline & & 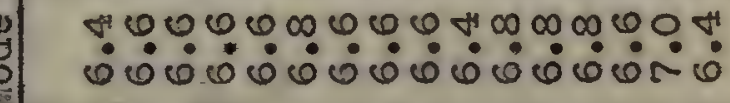 \\
\hline & 蛋 & 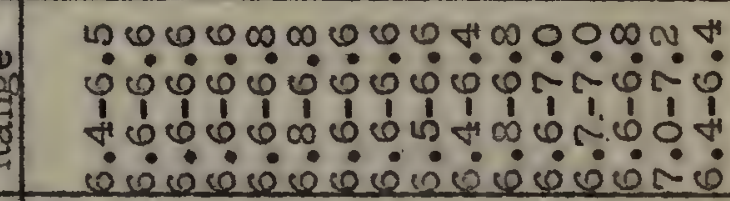 \\
\hline & & 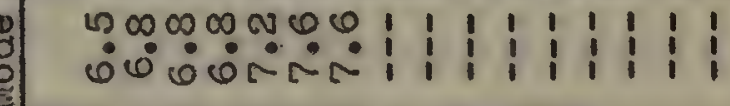 \\
\hline$\stackrel{H}{H}$ & 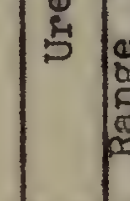 & 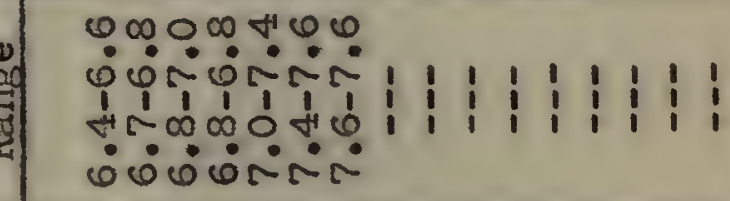 \\
\hline & $\stackrel{\oplus}{+}$ & 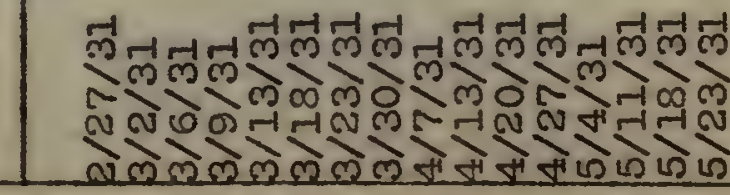 \\
\hline
\end{tabular}




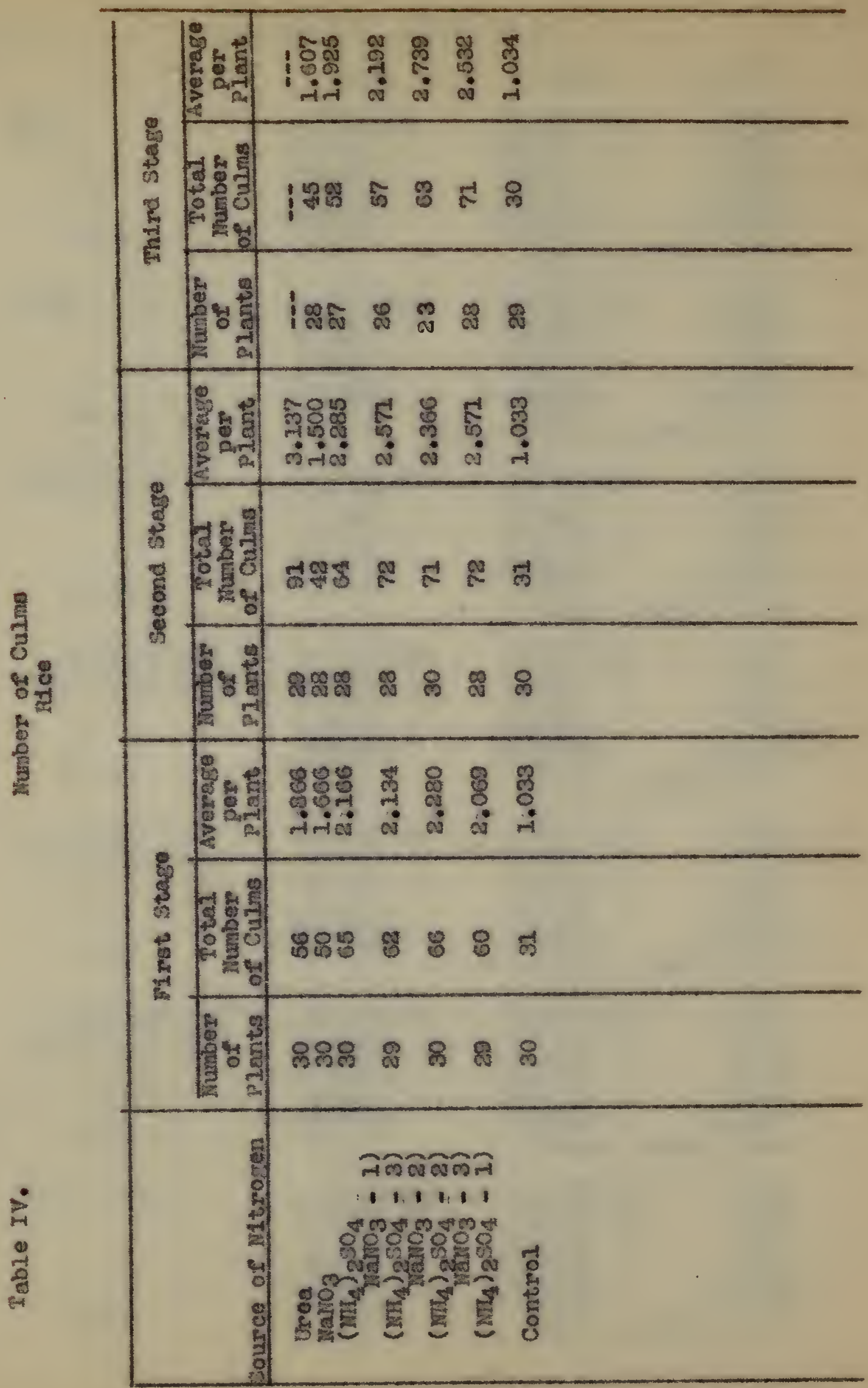


Tabie V. Rice Elarvest - First stage

Total

Togs

lroots

Total

urea

Total

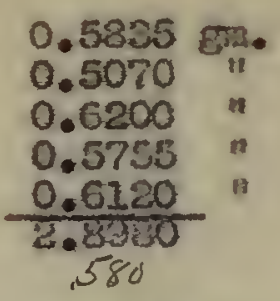

$\mathrm{FalO}_{3} \mathrm{Sodn}^{\mathrm{T}}$

Total

\begin{tabular}{l}
$0.3035 \mathrm{gm}$ \\
0.4600 \\
0.4685 \\
0.3305 \\
0.2430 \\
\hline 1.8105 \\
.362
\end{tabular}

$\left(\mathrm{m}_{4}\right)_{2} \mathrm{SO}_{4}$

$\mathrm{NaNO}_{3-1} \mathrm{pt.}$ ) (m/4) $2504-3$ pts)

Total

$0.5935 \mathrm{gm}$
0.5455
0.5840
0.6065
$\frac{0.6085}{3.1270}$
.625

$0.6485 \mathrm{gma}$

0.5185

0.5505

0.6350 a

$\frac{0.5685}{2.5600} "$ .592

Nanos-2 pts)

$\left.(m)_{2} \mathrm{SO}_{4}-2 \mathrm{pts}\right)$

Total

Nomes -3 pts)

$\left.\left(m L_{1}\right)^{S O_{1}-1} p t_{*}\right)$

Total

Check - No II

Total

\begin{tabular}{l}
$0.4540 \mathrm{gm}$ \\
0.7365 \\
0.6580 \\
0.5320 \\
0.7395 \\
\hline 3.1105 \\
.621
\end{tabular}

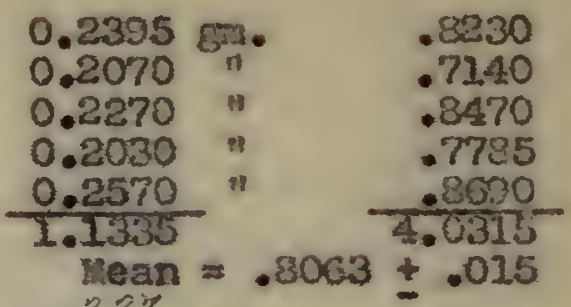
$12: 27$

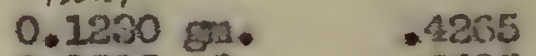

0.1895 n .6495

$0.2450 \mathrm{n} .7135$

0.1635 " .4990

$\frac{0.1400}{.0650} " \frac{.3080}{2.6705}$

193 Mean $=.5353 \pm .032$

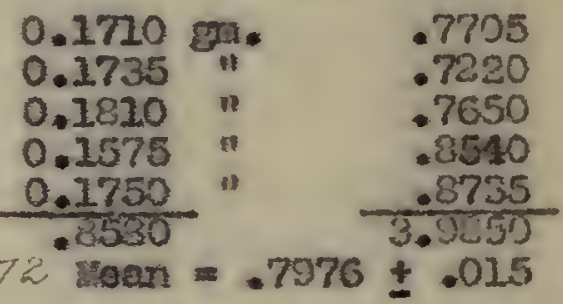

.172 vean $=.7976 \pm .015$
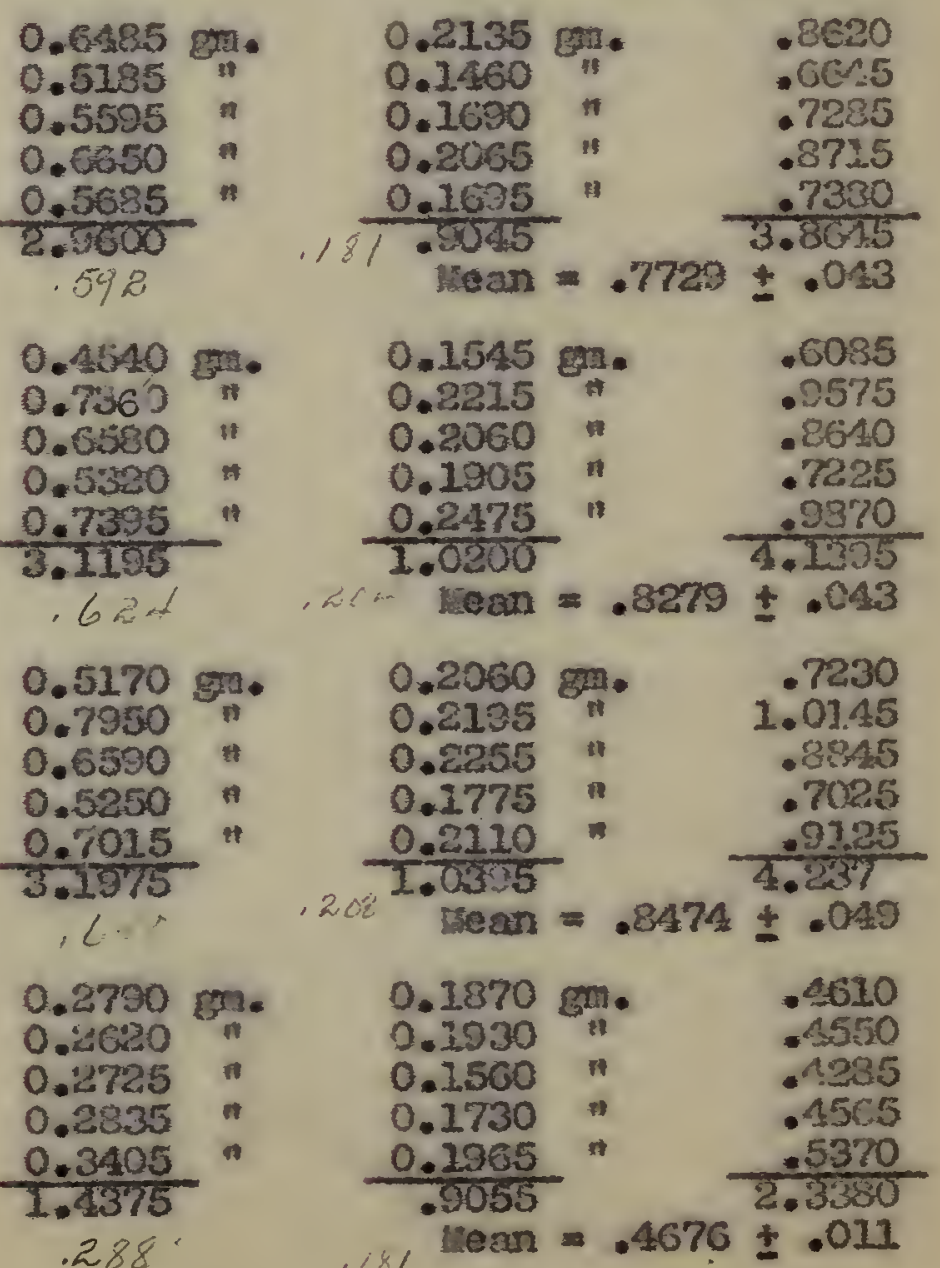

.4610

.4550

.2035

.1565

$\frac{.5370}{2.3380}$

$.288^{\circ}$

tiean $=.4676$

$+.011$ 
Urea

Tota1.

$\mathrm{NaNO}_{3}$

Totel

$\left(\mathrm{NL}_{4}\right)_{2} \mathrm{SO}_{4}$

potal

Topo

$1.9516 \mathrm{gm}$
1.9330
2.2933
1.2036
$\frac{3.2707}{10.6582}$
2.132

3.2019
$\frac{1.7938}{2.1661}$
$\frac{1.5430}{2.7672}$
$\frac{1.5570}{2.311}$
2.

$$
\begin{aligned}
& 2.9700 \text { m } \\
& 2.7875 \\
& 2.9711 \\
& 2.29130 \\
& 3.4448 \\
& 15.0864 \\
& 3.077
\end{aligned}
$$

$\left.1 \mathrm{Fan}_{3}-1 \mathrm{pt}\right)$ $\left(\operatorname{mit}_{4}\right)^{50_{4}^{3}-3}$ pts)

Totaz.

$$
\begin{gathered}
3.2974 \text { B2. } \\
2.5257 \\
2.2437 \\
3.3650 \text { " } \\
\frac{3.7601}{13.2019} \\
3.052
\end{gathered}
$$

$\mathrm{NaHO}_{3}-2 \mathrm{pts}$

$\left.\left(\operatorname{mu}_{4}\right)_{2} \mathrm{so}_{4}-2 p t\right)$

Total

$$
\begin{gathered}
3.5077 \text { " } \\
2.2260 \\
3.2600 \\
3.5025 \\
\frac{3.0023}{17.0331} \\
2.0
\end{gathered}
$$

HaMOs - 3 pts)

Tota1

$$
\begin{aligned}
& \text { Check - No N } \\
& \frac{1.2131}{3.1437} \mathrm{~g} \text {. } \\
& 1.1050 \text { " } \\
& 0.2352 " \\
& \frac{1.0303}{5.1365}
\end{aligned}
$$

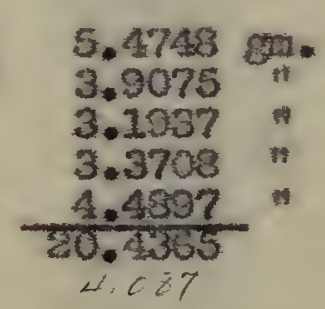

$\left.\left(m_{4}\right) \mathrm{zon}_{4}-1 \mathrm{pt}\right)$

Roots

Total

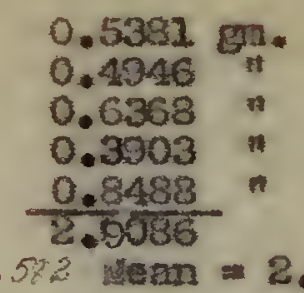

\begin{tabular}{|c|c|c|}
\hline $\begin{array}{l}0.6256 \\
0.5634 \\
0.5254 \\
0.6247 \\
0.0211 \\
3.2602\end{array}$ & 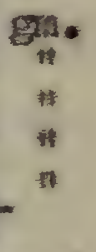 & $\begin{array}{r}4.1333 \\
3.4304 \\
3.7260 \\
4.1272 \\
4.8231 \\
20.3503\end{array}$ \\
\hline
\end{tabular}

2.4397

2. 4276

2.2301

1. 5039

4.1255

13.5008

.522 Mean $=2.7134 \pm .248$

$0.3336 \mathrm{~m}$
0.5553
0.6370
0.4321
0.8335
3.5115

4.2855

2. 3441

2. 8031

2.0351

$15.00+35$

$.70 \% \tan =3.0137 \pm .248$

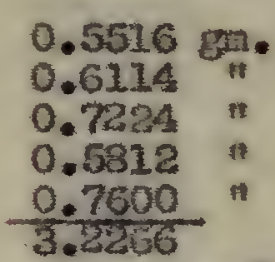

645 tean $=3.6626 \pm .036$

3.3900

3.6335

3.1932

4.2048

$0.5835 \mathrm{ma} . \quad 3.3809$

$0.4924 \quad 3.0831$

0.1250 ₹ 2.0057

0.6715 * 4.0360

$\frac{0.7960}{2.3598} * \frac{4.5561}{15.2317}$

$59+\operatorname{Mean}=3.6463 \pm .204$

.652 .1 roan $=1.0719 \pm .138$

1. 0434 . ㅁ.

6.5232

0.7153 .

4.7675

0.0437 a.0145

$\frac{0.0662}{2.736}=\frac{5.4559}{24.6701}$

, w7 lean $=4.9340 \pm .292$
2. 0023

1.8375

1.8112

1.6029

$\frac{1.7598}{9.1237}$ 
Table vII.

Total

$\left(\mathrm{M}_{4}\right)_{2} \mathrm{SO}_{4}$

Total

farro $3-1$ pt.) $\left(\mathrm{mH}_{2}\right)_{2} \mathrm{SO}_{4}-3$ pts)

Total

$\mathrm{NaNO}_{3}-2$ pts) $\left.\left(m_{4}\right)_{2} \mathrm{~s}_{4}-2 \mathrm{pts}\right)$

Total

$\mathrm{NaHO}_{3}-3$ pts) (ntys) $)_{2} \mathrm{SO}_{4}-1$ pt.)

Total

Control

Total nice Ilarvest - Third stage

Tops

Roots

Total

$5.7115 \mathrm{gm}$
$5.0805 "$
6.3454
2.4034
$\frac{3.0457}{25.1765}$
5.035

$5.3480 \mathrm{gm} *$
$5.4740 \mathrm{n}$
4.2107
$1.2000 "$
0.3862
17.1182
3.424$$
1,3.9
$$

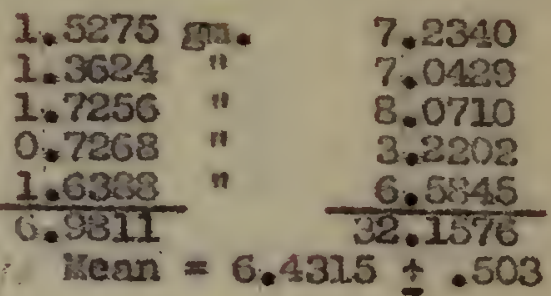

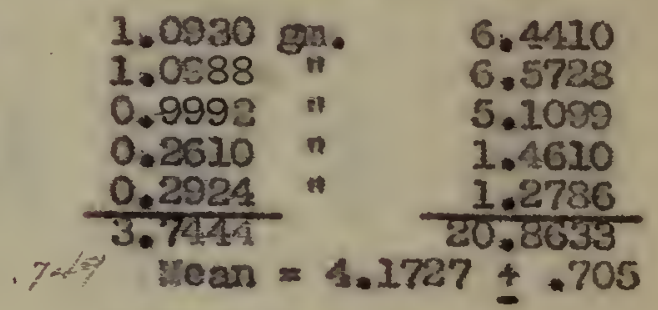

$3.1504 \mathrm{gm}$.
2.7610
6.4250
$1.4072 n$
$\frac{2.8287}{16.0343}$
3.386

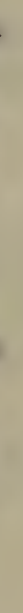

56

$0.4526 \mathrm{gma} \quad 3.5030$

$0.4126 n$

1.1480 *

3.1736

0.2780 a

$\frac{0.5536}{2.8154}$

3.3923

Hean $=3.9555 \pm .533$

$7.7330 \mathrm{~m}$
7.6383
7.5532
2.0654
$\frac{5.3300}{30.3753}$
$6.7 \%$
2.0311 gुa 8.7701
$1.0030 "$
8.7573
$1.0014 \pi$
$0.3300 " 1$
$0.7340 " 6.0540$
4.2255
3..6014
.845 tean $=6.9203 \pm .733$

\begin{tabular}{c}
10.2400 \\
6.3435 \\
7.7490 \\
$6.7140 "$ \\
$10.3060 "$ \\
\hline 12.5525
\end{tabular}

1.3332 gm. 11.5732

0.8350 in 7.7735

$1.0122 " 8.7012$

$1.1100 " 7.8336$

$1.4000 n \quad 12.3060$

$5.7000 \quad \frac{12.3050}{43.2525}$

8.511

$1.140 \operatorname{maan}=9.6505 \pm .576$

$1.6358 \mathrm{gm}$
1.3413
1.1710
1.2133
$\frac{1.1253}{6.1867}$
1.247




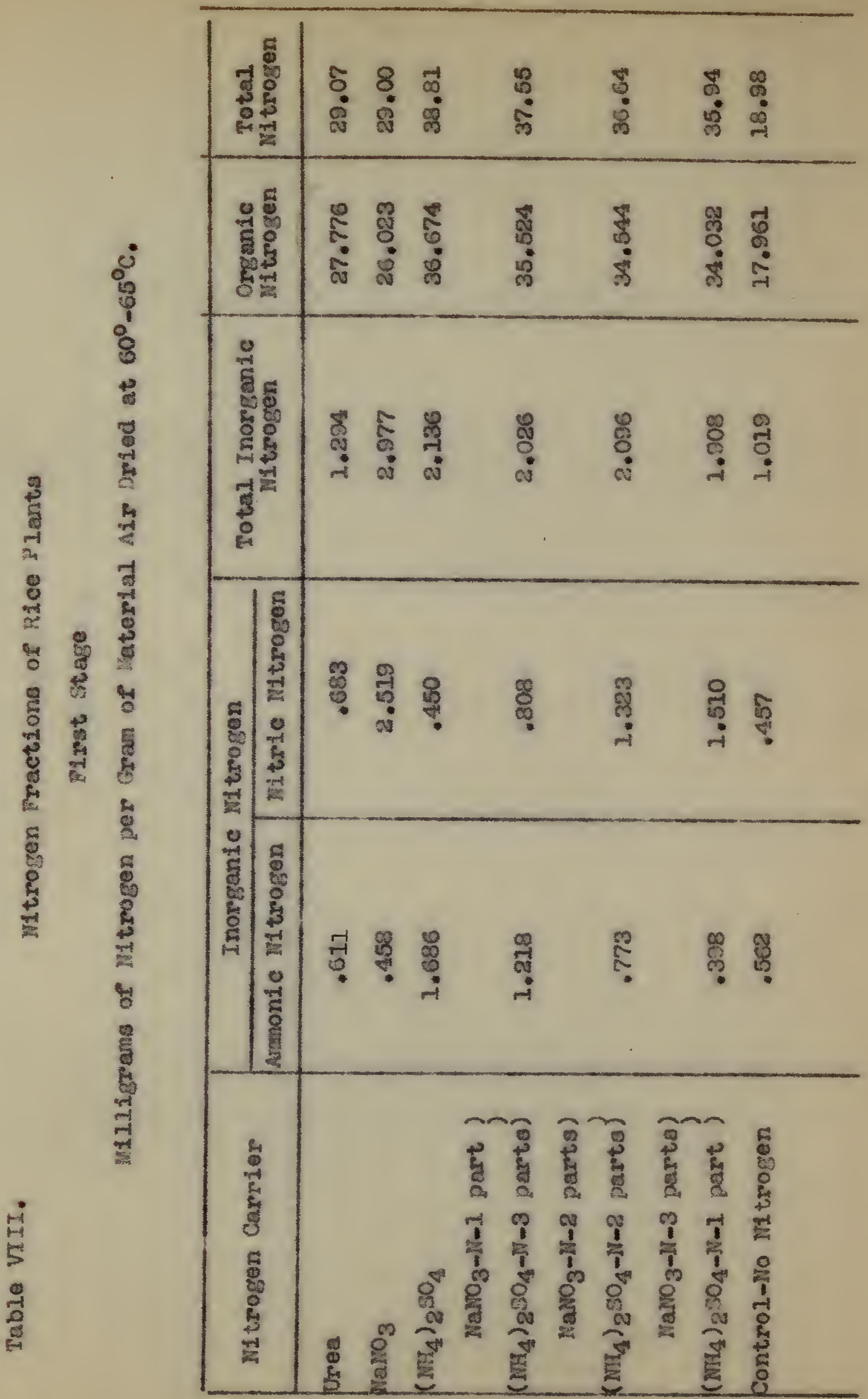




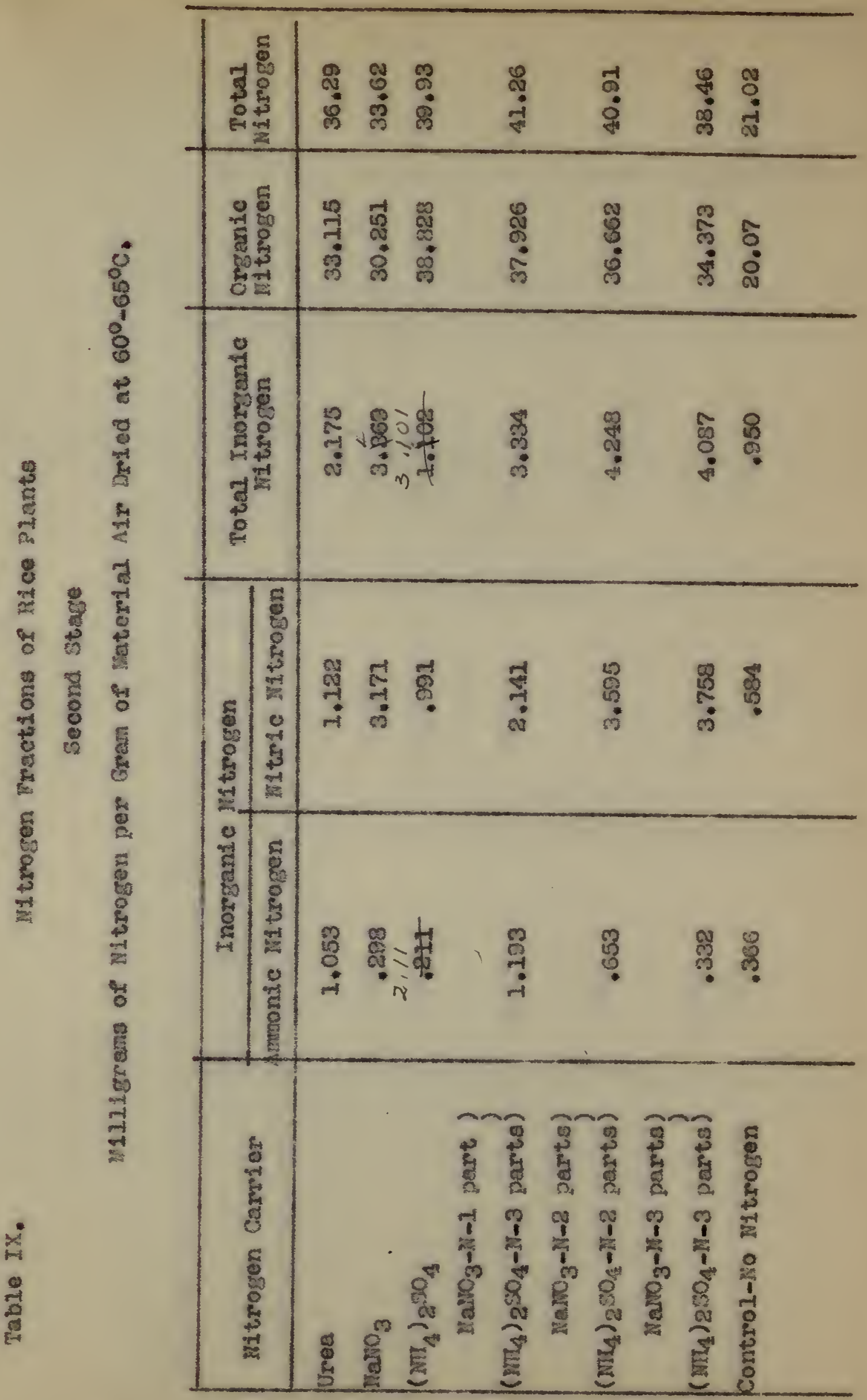




\section{$-68-$}

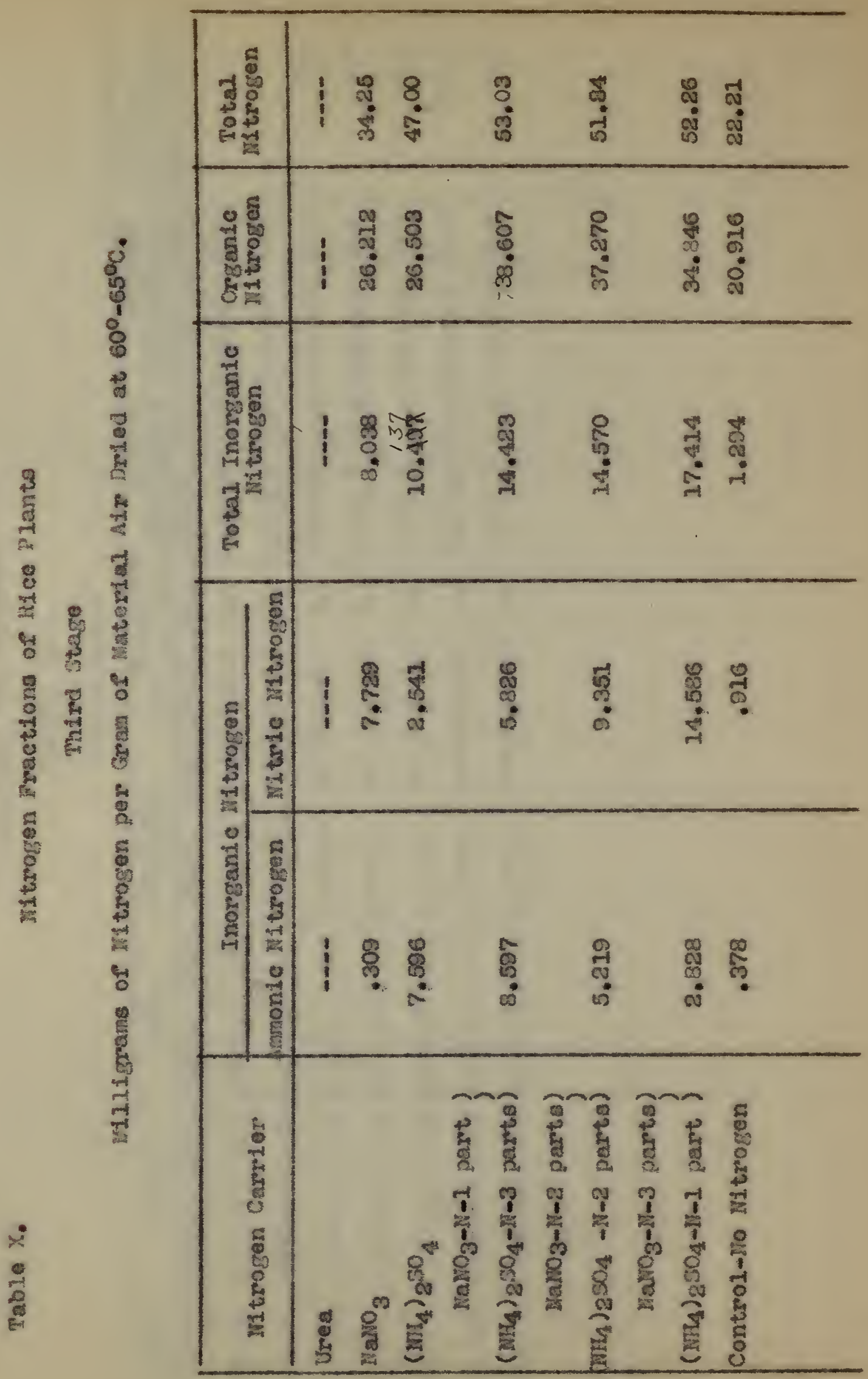


$-69-$

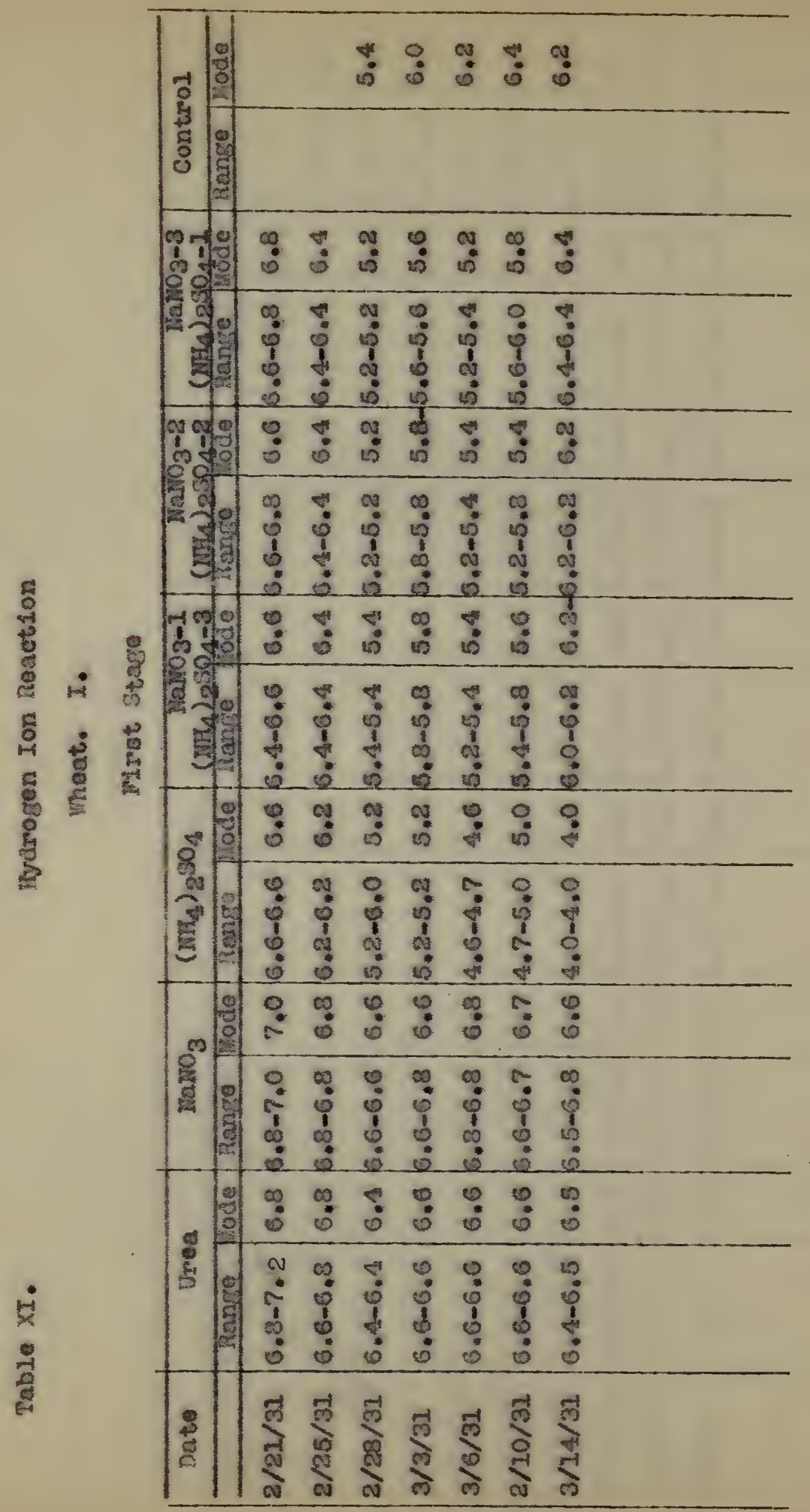




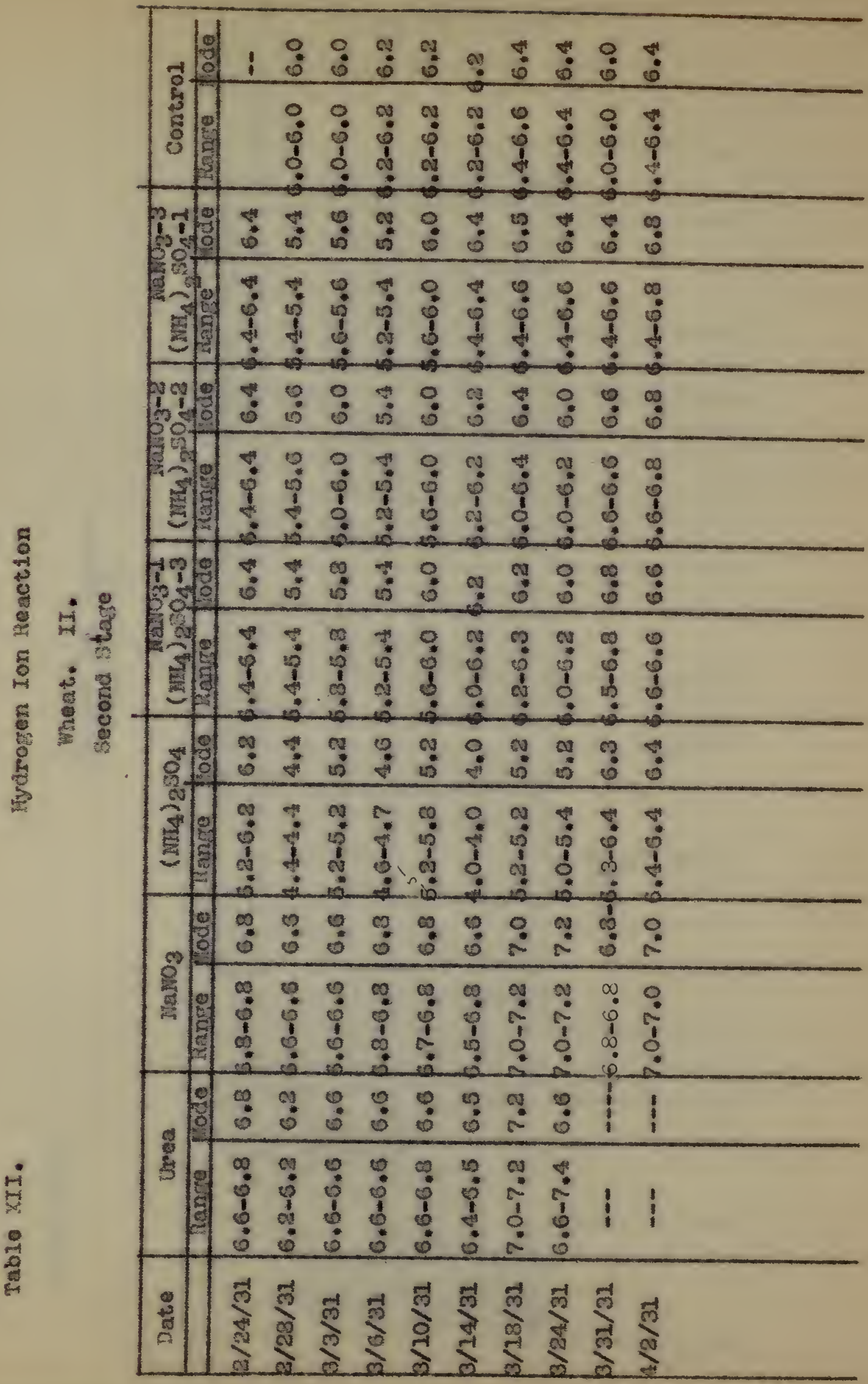




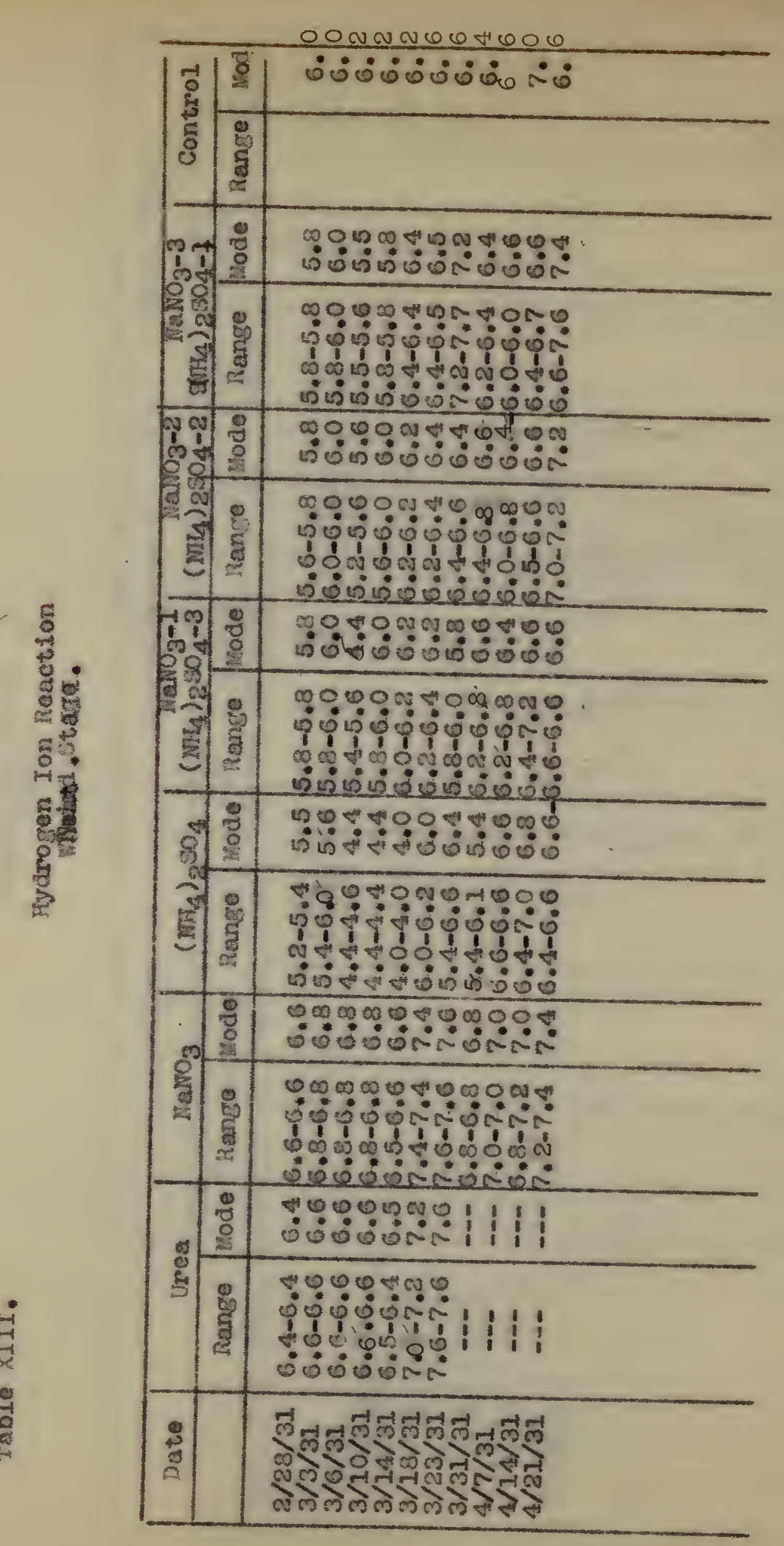




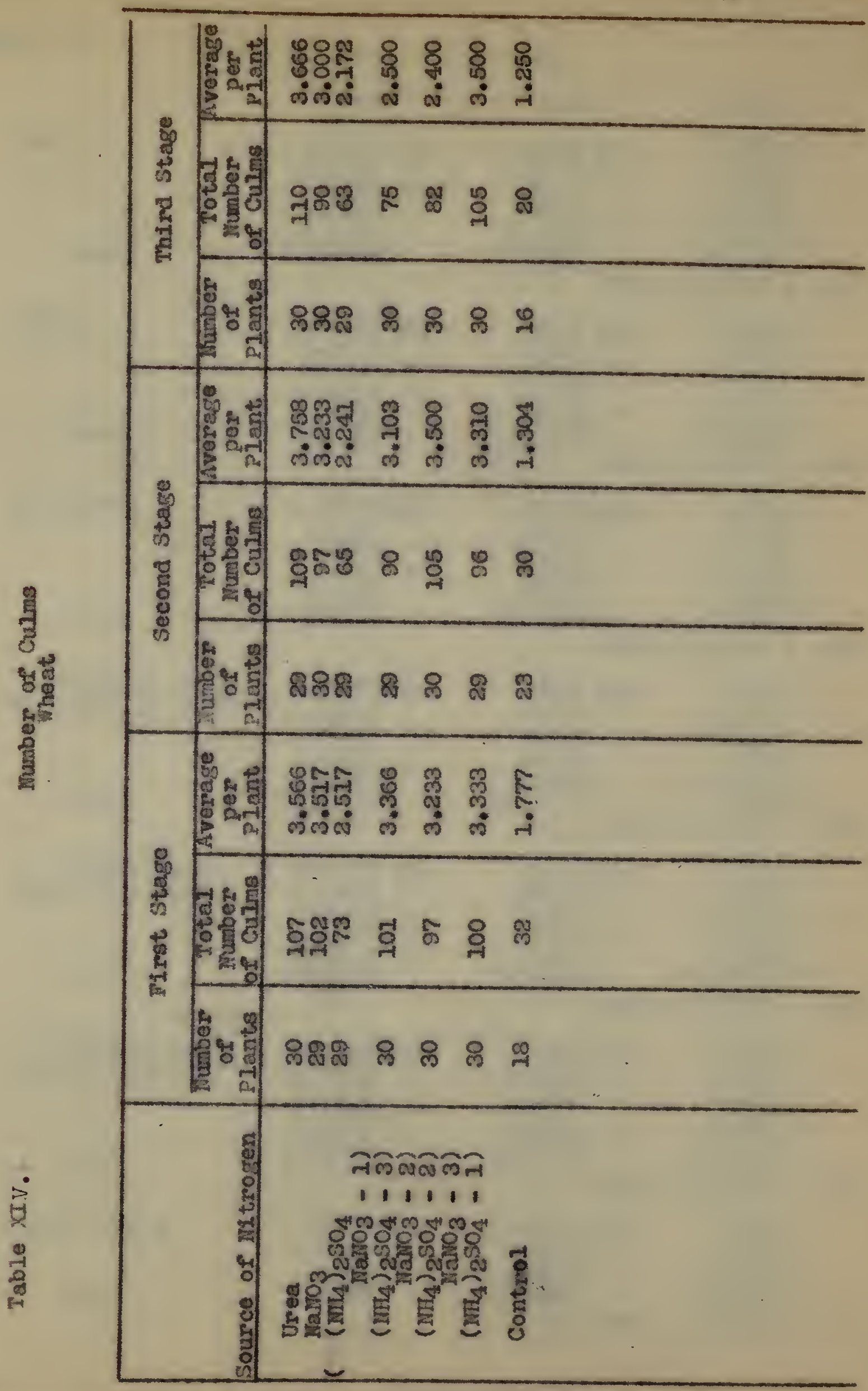


Table XV.

wheat Harvest - First stage

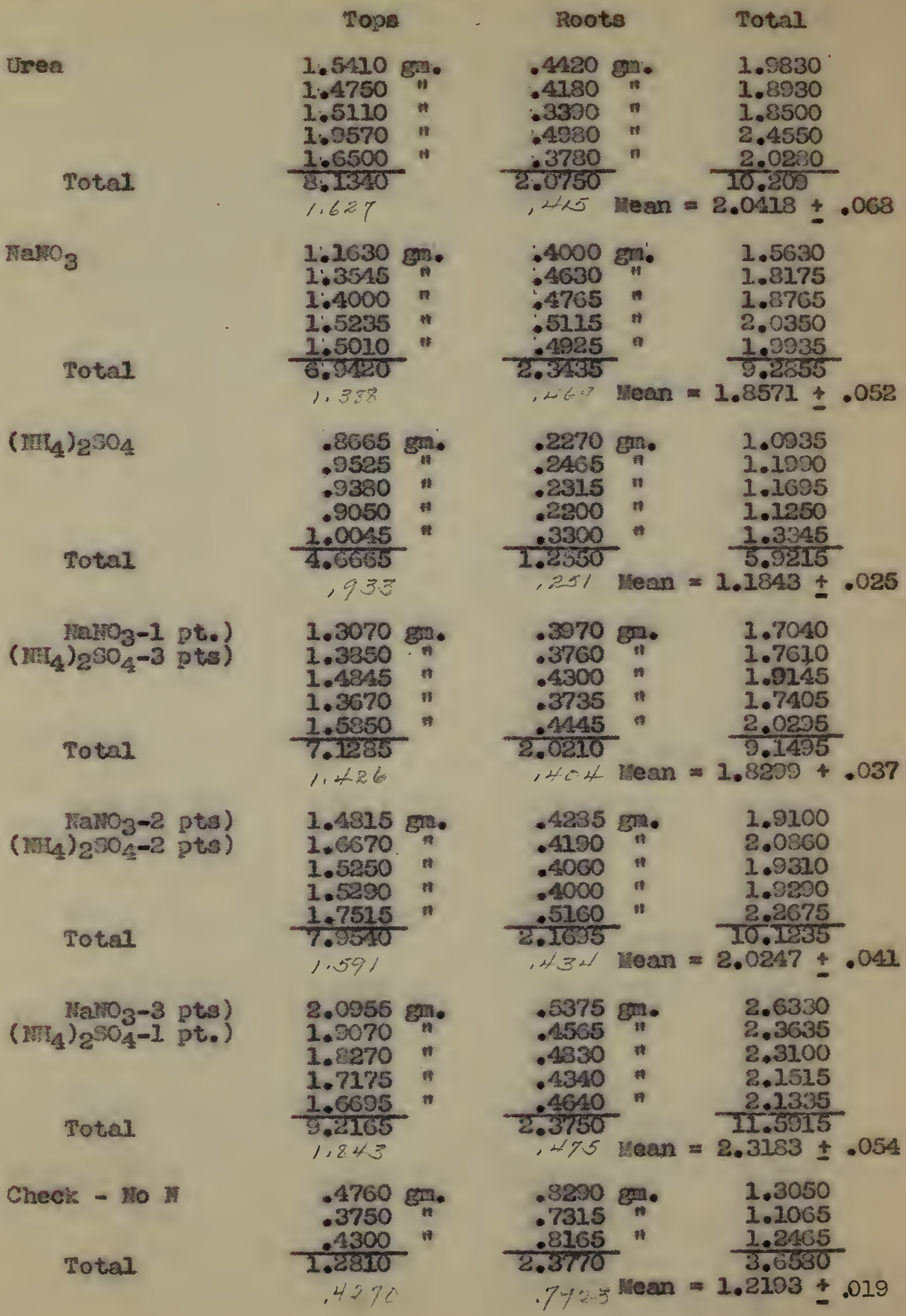


Table XVI.

tirea

Tota1

$\mathrm{NaNO}_{3}$

Total

$\left(\mathrm{mL}_{4}\right)_{2} \mathrm{SO}_{4}$

Total

Hallo -1 pt.)

(mu) $2503-3$ ptis)

Total

Nal103-2 pts)

$\left.\left(\mathrm{HL}_{4}\right)_{2} \mathrm{SO}_{4}-2 \mathrm{pts}\right)$

Total.

$\mathrm{NaHO}_{3}-3$ pte) $\left(\mathrm{MH}_{4}\right)_{2} \mathrm{SO}_{4-1}^{3-1} \mathrm{pt}$

Total

Check - Ho N

Total
Wheat Harvest - Second Stage

Tops

Roots

Total

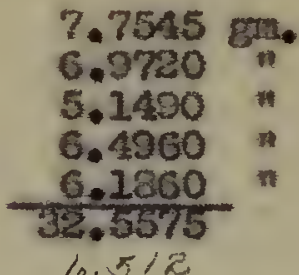

$1.4930 \mathrm{gn}$
1.3035
0.8900
1.1190
$\frac{1.0010}{5.8005}$

0.2475

8.3655

6.0330

7.6150

7.1900

30.4570

1.180 Mean $=7.6914 \pm .0325$

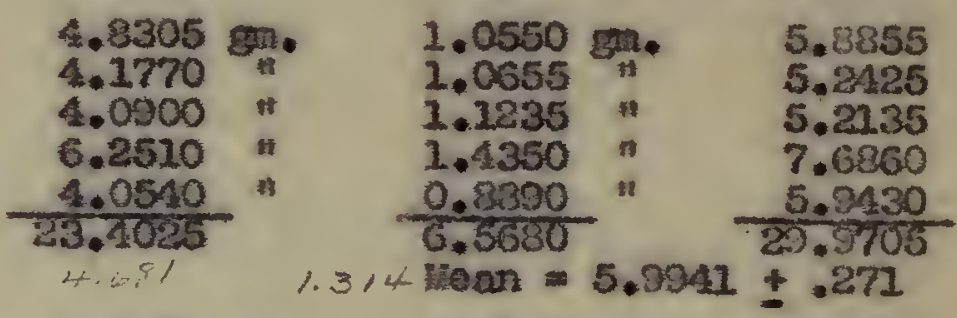

1.7430
1.2765
1.4685
1.2360
$\frac{1.2030}{6.5330}$
1.388

\section{(. 314 -}

0.3875 ต2. 2.1355

$0.2790 \mathrm{gs}$

$0.3545 n$

2. .5555

0.2420

1. 3230

1.4780

0.3835 " 1.5325

$1.6465 \quad \frac{1}{3.5815}$

329 moan $=1.7169 \pm .072$

1. 8005 다에

2. $2005 \mathrm{gm}^{2}$

$0.1250 \mathrm{gm}$

0.6320 "

2.2055

0.6320

2.8240

2.2495 n

2.7380

2.1620

0.5270

2.8805

* 3.3250

$-11,1930$

0.4720

.551 iean =

2.6300

13. 310

$\pm .093$

4.2370 gin. 1.2035 Em. 5.4405

2.3900 "

2.5060 "

3.8300

3.2285 *

16.1325

$3.23 \% \quad, 808$ tean $=4.0459$

$0.5230 \mathrm{gm}$.

0.5580 औ

2.9230

0.8675 "

3. 0610

4.6975

$0.8860 " 4.1145$

20.2205

$+.290$

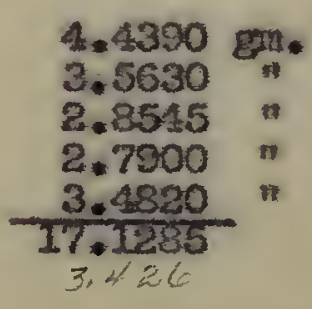

$0.8915 \mathrm{gm}$.

0.6670

0.7895

0.6990 "

5.3305

0.0655 "

4.0125

4.2300

3.6490

3.4300

203

Itean $=4.2232$

1. 4475

2I. 1310

$\pm .138$

0.9200
0.3170
0.9720
0.8900
3.6590
.9247

0.75258 .
0.7635
0.7080
0.6050
2.3340
lean $=1.6333$

$7 i 85$
1. 6725

1. 6355

1. 6800

1.4950

6.5330

$\pm .023$ 
Table XVII.

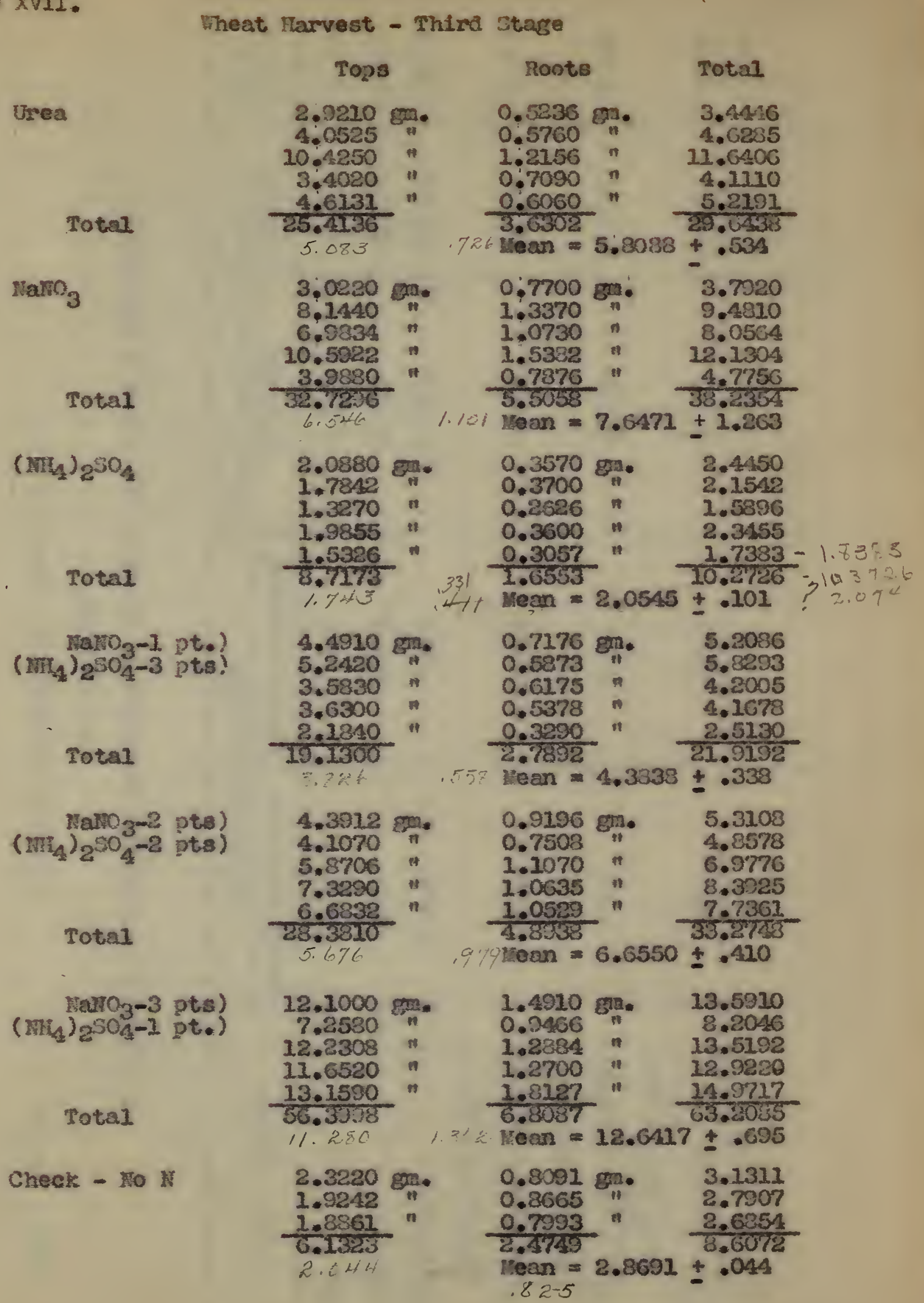


$-76-$

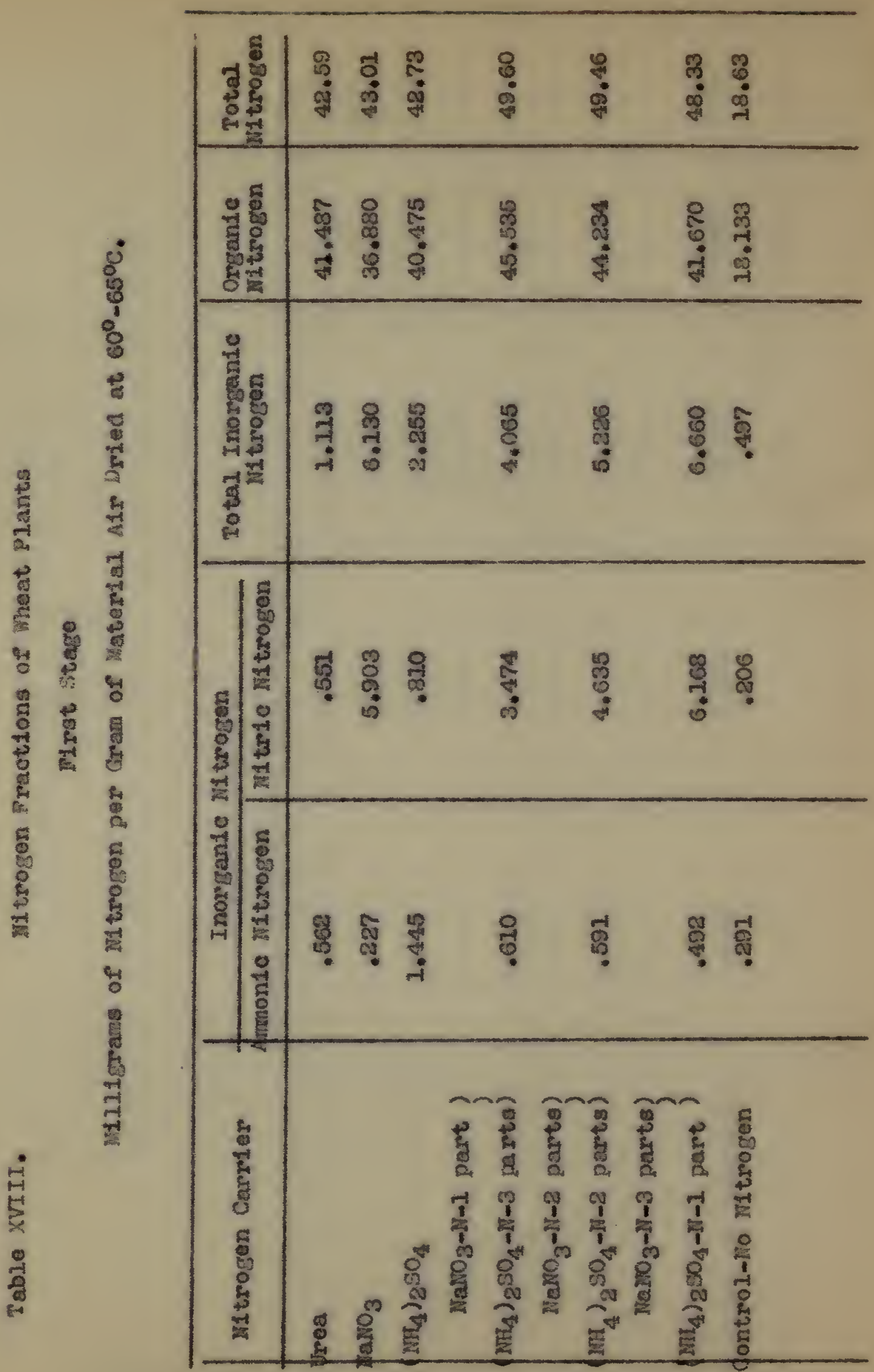




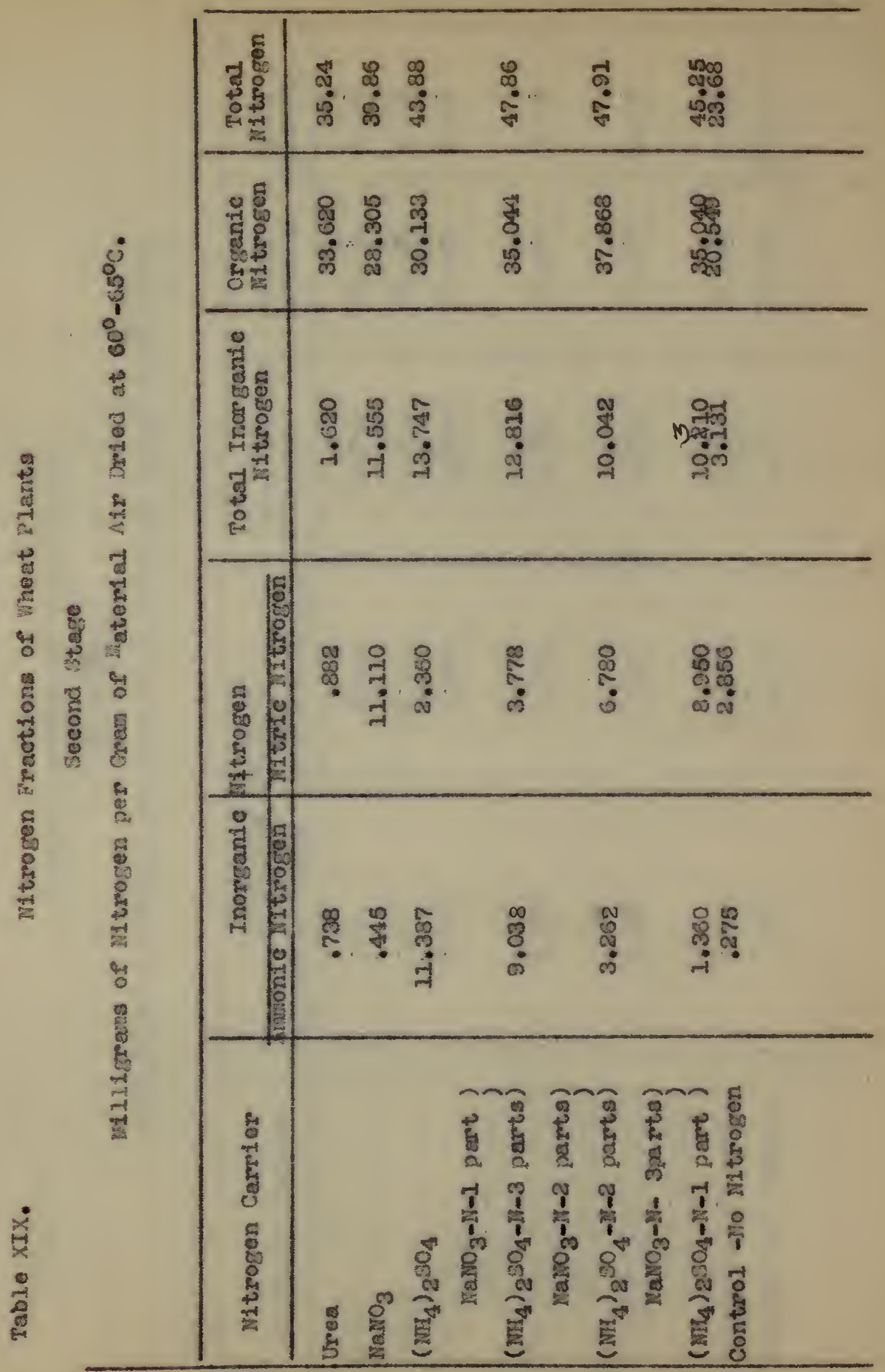


- is -

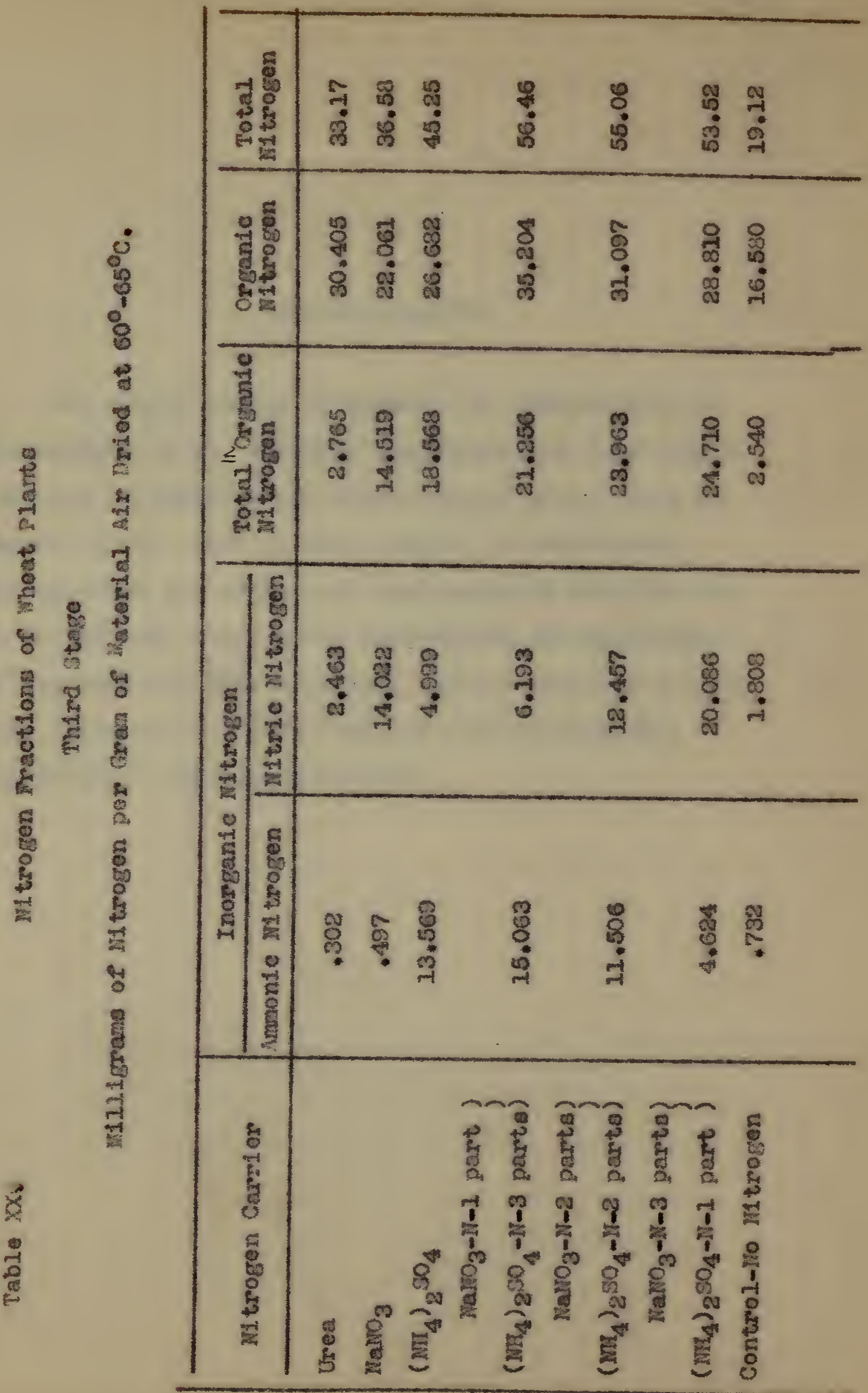


The author wishes to express his appreclation to the members of the Agronory hepartment for theis loyal Eupport, suggestions and encouragement given while engaged with the work of this thesis. Me especially acknovleages the advice and encouragement given by $\mathrm{Dr}$. A. B. Meaunont under whose supervision the completion

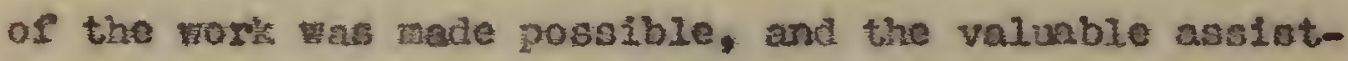
ance gtven by $\mathrm{kr}$. P. S. Smith of the thasachusetts Agricultural sexperinent station. 
Approved by
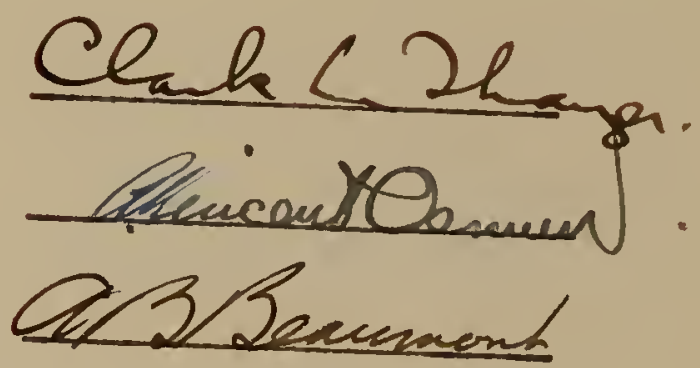

Committee on Thesis.

Date 
